\title{
Cricket heroes vs celebrities: assessing the role of media in framing Indian and Sri Lankan players using a Performance-Character Matrix
}

\author{
Thushara S. Kumar ${ }^{1}$ and Kalyani Suresh ${ }^{2 *}$ \\ ${ }^{\text {I} A m r i t a ~ V i s h w a ~ V i d y a p e e t h a m, ~ E t t i m a d a i, ~ C o i m b a t o r e, ~ I n d i a . ~}$ \\ ${ }^{2}$ Department of Communication, Amrita Vishwa Vidyapeetham, Ettimadai, Coimbatore, India.
}

\begin{abstract}
Despite prevalent and widespread knowledge about the characteristic nature of heroes and celebrities, research that relates media framing of a hero and celebrity in the cricketing sports arena remains scant. Therefore, the central purpose of this research paper is to develop the academic understanding of this topic by focusing on the relationship between cricket players (from India and Sri Lanka) and the print media. The researchers use media framing stages of Entman (1993), developed upon by Giles (2008) as dependent variables and investigate the influence of dimensions of the frame building process applied by journalists (cognitive, rhetorical and ideological) on the stages, leading to the final news story frame. A high/low hero/ celebrity-performance/character ranking matrix frame is thus created for cricket players that tries to show how journalists frame a specific cricketer in comparison to his cricketing peer.
\end{abstract}

Keywords: Cricket, media framing, India, Sri Lanka, hero, celebrity.

\section{INTRODUCTION}

\section{Cricket and the Media}

When commercialisation became an inseparable component in deciding the news priorities, sports in general and cricket, in particular, began to gain more media attention mainly because of the large amount of money involved. Further, due to branding, it has gained more significance and coverage than any other sport in India. When new multi-national companies entered India, it brought about a need of new faces as ambassadors. Cricket players were identified as the perfect vehicle. Further, the bourgeoning public attention to cricket has made it a dynamic topic for media. It is this commercialisation that makes the experience of reading newspapers pleasurable. Market driven content is promoted by the media due to the shift in emphasis to profit prioritisation. This has given life to new concepts like sensationalist and celebrity-driven journalism. Even though this has raised questions regarding journalistic ethics, it is welcomed by most advertisers. The type of news coverage that is given to cricket is also a key factor in its hype of popularity. Media reports about the game's win, loss or controversy about cricketers overshadow coverage of other games. The cricketers are shown in media as nothing less than movie stars and since the iron-field success is equated with nationalistic pride, they are given the mantle of a national hero. Recently, Sachin Tendulkar, the legendary player was given the highest civilian award of India, 'Bharat Ratna'. Thus, the statement, "Cricket is the religion and Sachin is the God in India" is not at all an exaggeration. Cricket stars are present-day royalty. Virat Kohli, for example, is "King Kohli" whose zone of influence spreads further than the cricket field.

Cricket may have its roots in England but it flourishes in South Asia, inspiring much fanfare while creating icons and mega stars. India and Sri Lanka share a colonial past

*Corresponding author (suresh.kalyani@gmail.com; (iD http://orcid.org/0000-0003-2897-4897) 
relating to the sport of cricket. Cricket was first played in 1721 in India and in the 1800's in Sri Lanka. In India, it is not possible for the nation to ignore sports, yet the emphasis given to cricket is a reason for the degradation of other sports including hockey, the national sport. Similarly, Sahajeewa's (2015) study on sport journalism coverage in leading Sri Lankan newspapers Diwaina and Dinamina talks about the huge slant towards cricket as compared to other sports such as volleyball (the national sport), football and athletics. In Sri Lanka, as Dunham \& Jayasuriya (1999) point out, cricket emerged as balm for a nation mired in ethnic conflict, oppression and poverty and also contributed to a national consciousness. Sport in Sri Lanka is an indelible part of its national culture.

\section{LITERATURE REVIEW}

\section{Foundations of Framing}

Framing has had an extended antiquity in the field of social science. Foundations of framing as a theoretical tool in academia could be gathered from the works such as Bateson's (1972) Concept of Frame as tool to comprehend etymological messages, Goffman's (1974) Notions of Frames as 'cognitive' constructs that delineate social conditions and Tversky \& Kahneman's (1981) Conceptualisation of Prospect Theory-the positive/ negative heuristic 'message frames' and their impact on judgment-making. At the media level, journalists' framing of an issue may be examined as a dependent or an independent variable (Scheufele, 1999). There has been very little systematic evidence about how various issues have a bearing on the operation of news in terms of the final framing of news stories, especially in the arena of sports reporting-particularly the link between stages of media frames as inputs (I) and other variables such as the frame building process $(\mathrm{P})$ and the resulting output $(\mathrm{O})$ presented in the news story.

\section{Mediated Frame Building- The Input}

Media frame building influences the structural qualities of news frames and is influenced by factors both internal and external to the media organisation (Shoemaker \& Reese, 1996). The outcomes of the frame building process are the frames that appear in the news article (de Vreese, 2005). Hallahan (1999) delineates the framing process constituting valence (positive/negative), semantics (phrasing of words) and rhetorical storytelling techniques, while describing the 'context' of framing of situations (social), attributes (description of objects, events, and people), choices (choice between options), actions (in order to achieve a specific goal), issues (alternate explanations of social reality between two or more people/groups) and responsibility (someone to be given accolades or held liable for an event). Waller \& Conaway (2011) add to Hallhan's (1999) work by operationalising the process of framing through cognitive, rhetorical and ideological dimensions. In the cognitive dimension, ideas and facts that are valuable to the frame's central theme are included. It is the mechanism through which people evaluate and make sense of situation leading to pursuing or avoiding subsequent action. The cognitive dimension has further subsets of frames such as (i) SubstantiveFocus on what issue is about; (ii) Outcome Based- Party's predisposition to achieving specific result/outcome from negotiation; (iii) Aspiration- Focus on satisfying broader set of interest or needs; (iv) Process Based- Focus on how/ process by which party goes about resolving issue; (v) Identity Based- Focus on how parties define who they are; (vi) Characterisation based- Regards how parties see and define other parties and (vii) Loss/GainRegards how parties define risk/reward association with particular outcome (thebusinessprofessor.com). The rhetorical dimension suggests ways of construing the ideas or facts using similes, metaphors, personification, and comparison. Franzosi \& Vicari (2013) provide a summary of academic work on Categories of Rhetoric in terms of Logos, Pathos and Ethos that are related to style (Diction, Sentence structure, Figures of thought, Figures of speech). The ideological dimension provides information on how society works or should work, social priorities and problems along with proper relation among members. As an illustration, scholars such as Clarke \& Clarke (1982), Hargreaves (1986) and Bryson (1987) situate sports news reporting within dominant patriarchal ideologies.

\section{Framing News Stories - The Process}

Entman's (1993) seminal analysis of the process of framing news stories identified four stages- (i) agency [an action (what) and a recipient to whom]; (ii) identification (with individuals); (iii) categorisation (labeling by using adjectives etc); and (iv) generalisation (with other news stories, prior discussions/arguments etc). Giles (2008) developed Entman's work further by adding a fifth stage which he termed as 'narrative', to account for systematic styles of media storytelling that influenced the indigenous cultures. Giles (2008) also incorporates the study of 'dramatis personae' in Entman's agency frame - the characters that are part of the media narrative. Iyengar (1991) drew distinctions between episodic frames (that developed a narrative around a specific individual or a small group of individuals) and thematic frames (that dealt with abstract perspectives using narratives related to general situations or conditions). These initial studies demonstrated how frames channel attention towards 
definite aspects of media content and how reactions to that content could be influenced by the selection of frames by the producer of the content.

\section{Applying Entman's Process of Media Framing}

\section{(i) Agency-The Cricketer}

Hussain (2014), in his comparative meta-analysis of three newspapers: Times of India, Indian Express and The Statesman, finds a decrease in the number of hard stories on cricket and the tremendous rise in the number of soft stories for the sport. He finds, the national sport, Hockey, getting least coverage of all.

\section{(ii) Identification of Cricketer as 'Hero'or 'Celebrity'}

The World of Cricket provides the best example for the media created frenzy over heroism and celebrity. The rise of the sports celebrity is related to the commodification of sports culture. Critics have opined that the modern-day sports 'hero' is an inaccurate term for the sports 'celebrity'. In today's world it can be said that the hero is replaced by celebrity in the same way priests are replaced by psychologists. In short, hero is one who creates new ideas or action that have long term effect on the society, while the celebrity is a famous and widely accepted figure in the society. Sports and sports celebrities are now an intrinsic part of media ethos. They have been idolised for years and with improved technologies in broadcast and other interactive media, it seems that the celebrities are everywhere. Sports heroes also fit in as a national hero because they demonstrate determination, self-reliance, courage and adventure or is at least portrayed so. According to Shuart (2004), the powerful and domineering nature of mass media and its intervention in the rise of sporting heroes in the $21^{\text {st }}$ century was never expected but has happened.

\section{Social and Mediatized 'Hero'frames}

Berg (1998) identifies differences in characterisation of mythical and modern mediated heroes - in terms of their place in the human to god-like curve, their stature and acts of heroism. She classifies mediated heroes as more 'human', with far less stature and strength (intellectual and moral) than their mythological counterparts. Boorstin (1978) argued that persons who performed legitimate acts of heroism became celebrities through media's spotlight on their superficial physical appearance and prowess. This converted their traditionally labelled 'heroic' actions into 'human pseudo-events' that were more social and culturally engaging. This applied to modern sports heroes too. Old-style heroes can still be found in sports, but their representation also changes to a celebrity due to the speed and nature of modern media (Drucker \& Cathcart, 1994).

\section{Hero vs Celebrity}

The unseen hand of the media has been responsible for creating cricket heroes and villains. Berg (1998) discusses the etymological roots of the word 'hero' and positions it as cutting across culture and time, while Holt (1996) propounds national and societal fuelled points of parity and points of difference between sporting heroes and likens a sport bereft of a hero to a crown deprived of its prince. The media involvement in promoting an individual in macro cultural sense are now understood and accepted widely. The terms hero and star are being used as synonyms in today's world but actually the term hero has a history dated back to ancient folklore, where a hero had special qualities and distinguished talents. While the heroes in legends and folktales were characterised by heroic features, it is not the same for the stars. A number of people falling under various categories are defined as heroes though they may lack heroic characteristics like courage and self-sacrifice. That is one of the major reasons why contemporary stars and celebrities are treated as heroes. This imprecise use of language along with the use of such words in media has created a new meaning to hero and celebrity.

The hero has something innately special as per the historical view. Aristotle defines heroes as men who are god-like and exceptional so that they transcend all moral judgment or constitutional control by their extraordinary gifts. The story of heroism always emphasise on acts of morality, adventure, courage, honesty and sacrifice. The definition of heroism is time-bound and culture-bound. The heroes may include sufferers for a cause from all facets of life; social, political, cultural, spiritual, scientific, etc. Zimbardo (2007) opines that heroes can be "reactive" as well as "proactive". Reactive heroes are those who react in the moment without any pre-thinking or pre-planning. On the other hand, a proactive hero makes continual effort to expose a fraud or to achieve their goal. The line between hero and celebrity is blurred that some claim traditional heroes to be extinct while others argue that the traditional heroes are replaced by modern day celebrities. According to Drucker \& Cathcart (1994), heroism is not dead but the concept of what constitutes a hero is altered by global communication. Becker has termed celebrities as 'pseudo heroes' since they have assumed the role of traditional hero.

Heroes are present for a long time in human history. However, the argument is whether the traditional heroes are replaced by the contemporary heroes or not. Many feel that old-style heroes do not exist and the contemporary 
heroes are undeserving of such a title. According to them, the traditional heroes have deteriorated and exist as shallow celebrities. In contrast to this, there is an optimist side that claims traditional heroes are replaced by contemporary heroes, among which some may be celebrities. They argue this to be a good thing since this ensures wider recognition. One can go with a pessimist idea that the old-style model of heroism has come to naught, but for the optimists the idea of traditional heroes has not come to an end but has evolved into modern-day forms. In either case, the celebrities have the potential to be effective in promoting social issues, public opinions and brands.

The variance between a hero and celebrity could be analysed from a small definition. A hero is someone who has created long lasting impact on the society and is admired for his/her achievements and noble qualities, but may or may not be a well-known person. On the other hand, celebrity can be famous for reasons that may have less or no impact on the society. In the present world, celebrities are often created by global communication efforts. In the words of Brown (2010), "media companies and entertainment in collaboration with multinational companies are making personalities powerful sources of social influence". Researchers view today's heroes as famous because they appear in the media, rather than based on their talent. However, without media assistance, hero creation is unlikely to happen since they have an understanding that coverage of heroes will increase the viewership and circulation. Though the common ground between celebrity and hero is negotiable at the forefront, it is the notion of style over substance. Celebrity heroes become well known, not because of heroic deeds, but by self-promotion with performance (Brown, 2010) and is in more demand by the celebrity-crazed public.

According to Boorstin (1978), the hero was known by his/her accomplishments while the celebrity by his/ her image or brand. The hero is self-created while the celebrity is media-created. While the hero is a big person, the celebrity is a big name. Media is attributed a major role in the de- 'mythification' of the past heroes. Rojek (2006) coins the term 'invasive egoism' as an extension of Durkheim's concept of egoism (Durkheim, 1951). Invasive egoism creates extreme levels of identification between fans and their heroes, sometimes creating celebrities out of the heroes. Turner's (2006) extensive exploration of the implications and significance of celebrities throws up pressing concerns about the transference of the celebrity to the realms of banality, describing this as the 'demotic turn'. i. e. increased prominence of an ordinary person through mediated celebrity culture.
Rosen et al. (2016) corroborate with Dunham \& Jayasuriya (1999) by pointing out that even though all time Sri Lankan cricket giants and celebrity cricketers Muttiah Muralitharan and Kumar Sangakkara came from opposing ethnic groups, their bonhomie and mutual admiration made them transcend their celebrity status and be reminisced about by Sri Lankan people as heroes, who provided a distraction during tough times. On the other hand, Naha's (2012) article of the print media depiction of the Indian cricketer C. K. Nayudu in relation to cultural discourse in the public sphere is a study in contrast. Unpopular within his own team, Nayudu, managed to rouse more heroic fan-following and cult status than any of his peers in his country, while breaking down stereotypical approach of a hero as defined by 'European masculinity'. The author ponders on the promotion of individual sportspersons as celebrities, through dramatisation of their on-field notable achievements as well as their failures, in order to commercialise the game. Chalip (1997) is of opinion that a sports celebrity can be a result of sports heroism but heroism does not mean that the person is a real hero- this corroborates with the fact that, unfortunately in most cases, it is the media that fake this heroism. Thus, this research makes an attempt to rate the sports stars in a hero/celebrity matrix. The research expects this to be helpful since this approach is not taken in the Asian sports scenario even though sports have gained wide recognition and acceptance from people.

Ganguly (2005) discusses global media's revenue generation format and a national consciousness output, as the outcome of the synergy between culture and politics of cricket in South Asia; a strain of thought that extends into Mukharjee's (2004) proposition about media's ability to create sporting 'celebrities' in the public sphere, out of a mixture of showbiz culture, societal attitudes and the sport itself. Beck \& Bosshert (2003) similarly explore the historical evolution of mediated dramatisation and personalisation of sport events leading to production of sensational/human interest stories. It is evident that the media has improved the status of players and instead of being a cricketer, a youngster dreams of being a Kohli, Dhoni, or Sangakkara, the thought which stems from the portrayal of these personalities in the media.

From a meta-analysis of literature on heroes and celebrity characteristics, Lewis \& Weaver (2013) come up with unique dimensions or key frames that characterise a hero and celebrity individually and the frames that denote the confluence of both heroes and celebrities (Table 1).

Shuart (2004) had also claimed that every sports star the media raises as a hero may not be a hero in reality and could be a 'celebrity trope'. He provides a framework for 
Table 1: Unique and Common Hero and Celebrity Dimensions

\begin{tabular}{lll}
\hline $\begin{array}{l}\text { Unique dimensions } \\
\text { Hero }\end{array}$ & Celebrity & Dimensions common to Hero and Celebrity \\
\hline $\begin{array}{l}\text { Inspirational } \\
\text { Leadership }\end{array}$ & Likeable & Ordinariness \\
& Attractive & Drive for affiliation \\
Dimensions of opposing views & & \\
Moral & Credible & Competent \\
Good & Genuineness & Shallowness (competence maps to lack of shallowness) \\
Strong & Exciting & Flawed Complexity \\
Active & Sociability & Compartmentalisation \\
\hline
\end{tabular}

Source: Lewis \& Weaver (2013)

studying celebrity and hero tropes. He classifies the heroes and celebrities in a matrix with four quadrants: - Low/ High; Hero/Celebrity. Nalapat \& Parker (2005), in their review of Sachin Tendulkar's autobiographical profile through the lens of politics, religion and nationalism suggest that such a study would afford a chance to observe, interpret and analyse cultural change. They opine that even though Tendulkar has all the characteristics of a celebrity, the rootedness of his nationalistic values affords him the iconic status of both hero and celebrity at once. As per Shuart's (2004) classification, Tendulkar can be "High hero, High celebrity" while other players who featured in advertisements during the Indian Premier League (IPL) season are either "Low hero, Low celebrity" or "Low hero, High celebrity". Sreekumar (2016) analyses the journalistic approach of Indian and non-Indian newspapers in their representation of Sachin Tendulkar's retirement. He sees more objectivity and less idolisation in the non-Indian newspapers, while the approach of the Indian newspapers was more subjective, celebrating his performance, humility of character and recurrently affording him the status of an Indian hero/ celebrity.

\section{(iii) Categorisation of Cricketer as Character vs Performance oriented}

\section{Mediated Sports 'Phenoms'}

Lewis \& Weaver (2013) discuss the varied coverage of "sports phenoms" as a function of extensive reporting in the news cycle; the more the coverage, the greater chances of the sport phenom's persona comprising of more than just their performance-related information. A rise in their popularity leads to more stories about their off-the-field life. Hussain (2014) also finds parallel evidence for the rising importance given to individual players-their behaviors on the field as well as off-with their personal life also finding its way into the sports page.
Thus, sports journalism narratives focus on 'performance' frame, while other stories thrive on information about the sportsperson's personal life through the 'character' frame. Within these two frames, one can distinguish good/bad performance frames and good/bad character frames. Hanson (2017) lists character and performance qualities under one umbrella, with the strength of personal character being the motivational force for performance. Personal character qualities are kindness, generosity, respect, honesty, honour, toughness optimism, positivity, determination, compassion, empathy, patience and truthfulness; and performance character qualities are perseverance, self-discipline, competitiveness, accountability, focus, hard work, mental toughness, bravery, resourcefulness, self-control, creativity, challenge-seeking, adaptability, confidence, reliability, ambition and critical thinking. Harris (1994) summarises the debate on whether celebrities are modern-day heroes and analyses it in terms of three dimensions:(1) shallowness or the depth of character/ or lack of; (2) flawed complexity that relates to the fact that extensive exposure by media would not only highlight the hero-like characteristics but also make them 'infamous' through exposing their flaws and (3) compartmentalisation-in terms of narrowness of scope of appeal.

Bolognani (2011), in his case study of the Pakistani fast bowler Shoaib Akhtar, refutes the Jungian models of celebrities as transcultural and trans-historic and argues their rootedness to social, political, cultural and historical foundations in a South Asian context. To leave an impression on audience perceptions, sports celebrities have to echo with their cultural backgrounds, with their on-the-field talents being a microscopic part of their makeover from skilled people to stars. As examples to illustrate, parallels can be drawn from two accounts: one being Krishnamohan's (2017) discussion of Sri Lankan media's villain-like portrayal of cricketer 
Lasith Malinga, a 'hero' performer in his own team. Malinga's rise to fame can be chronicled from his humble beginnings in Sri Lanka; he who nevertheless did not lack in morality, meticulousness or strong will. His phenomenal conquests in the national sporting pitches were not given much importance in the media as he had no famous background to highlight. He became infamous only when he sported a 'boorish' hairstyle and a 'devil-may-care attitude' $-\mathrm{a}$ 'rogue' cricketer among colonially-rooted stylish sportsmen. His lack of fitness, his 'huge' disposable income and lack of respect for authority were all highlighted.

The other account to exemplify Bolognani (2011) is from an article by Bull (2015) in The Guardian, extolling Kumar Sangakkara's exemplary off-the-field character that added to his on-the-field exploits and made him a selfless statesman and an inspiration for many. Bull (2015) quotes Sangakkara's 2011 'Spirit of Cricket' lecture :

" My loyalty will be to the ordinary Sri Lankan fan ... they are my foundation, they are my family. I will play my cricket for them. Their spirit is the true spirit of cricket. With me are all my people. I am Tamil, Sinhalese, Muslim and Burgher. I am a Buddhist, a Hindu, a follower of Islam and Christianity. I am today, and always, proudly Sri Lankan”.

North et al. (2005) found common characteristics between framing of heroes and celebrities that seemed to blur the lines between their individual conceptualisation-these were 'ordinariness' i. e. a 'common man' characteristic of the sportsperson; and 'drive for affiliation'-the need to be associated with characteristics of a hero or celebrity.

Focusing on Australian journalists' coverage of sporting celebrities, Waller \& Oakham (2009) identify the practice of negative framing of sporting heroes, by juxtaposing their on-the-field superhuman achievements with their off-the-field human infirmities. Critcher (1979) follows the footballer's evolution from a local working class person-to hero-to a modern day celebrity through a sequential classification of personality fashioned by culture, namely, traditional-located (where they remain rooted to their working class values); transitional-mobile (where they are affluent, yet maintain their rootedness to their working class values) ; incorporated-embourgeoised (where greater affluence afford them new opportunities to look beyond their rootedness) and supertars-disclocated (where the sportsperson goes through an unbalanced dislocation from his/her community, unable to manage his/her star status).
Ferriter (2008) identifies a set of sporting (which could run parallel to the performance frame) and social values (parallel to character frame) from her analysis of sporting events between 1994 and 1996. The social values include commitment, team-spirit, hard work, determination, equanimity/composure, maturation following (socially acceptable) rashness/irresponsibility, crucial decision-making, charity work, marriage (and divorce) and parenthood. The sporting values include extraordinary skill/talent, diligence/perseverance, obligation/commitment, passion, sustaining injury or being ill, overcoming injury/illness to accomplish extraordinary acts, leadership, team-spirit, humility, strength/endurance, equanimity/composure and self-assurance/confidence. One can see overlapping dimensions of both sporting and social values.

\section{(iv) Generalisation}

This defines the context in which the agency (cricketer in this study) is being framed-such as situations (social), attributes (description of objects, events, and people), choices (choice between options), actions ( in order to achieve a specific goal), issues (alternate explanations of social reality between two or more people/groups) and responsibility (someone to be given accolades or held liable for an event).

\section{(v) Narrative storytelling style of media}

\section{Narrative Frames and Image Building}

While for celebrity film stars, it is, most of the time, difficult to endure the thought that their prominence comes from their natural talent, the sports industry allows for a basis for sustaining of this belief through structured ranking of players, training and frequent competing opportunities (Giles, 2000). The writers and editors of sports stories determine how sportspersons are depicted in the media, including the attributes of the sportsperson and the narrative style of the media content. This, in turn, could affect media recipients' perceptions and evaluation of the sportspersons (Price et al., 1997). Polkinghorne (1988) defines narrative as essential in forming associations between human actions and events into interconnected parts of an understandable whole. Kennedy \& Hills (2009) envisage sport as a powerful lens for facilitating social meanings, associations and feelings, while Boyle \& Haynes (2009) describe it as a focal element of conventional narration of popular culture.

Whannel (2002) describes thirteen mediated narrative functions: the arrival of an outstanding talent, the achievement of an extraordinary deed, public 
celebration, repeated transmission of image of the star, shows of haughtiness/ego, lack of capacity to deliver, public doubt, unpredictable behavior, public disgrace, failure, the hero brought back by extraordinary performance, forgiveness and waning of power. These functions aid in the formation of a crafted narrative of sport celebrities that follow their rise, fall and recovery. This crafted 'sport narrativisation' allows them to have broader social connotations. On a similar note, Wenner (2013) studies the narrative trajectory of contemporary sports celebrity (star athletes, coaches and sportscaster) from a hero to villain (the sports anti-hero)-from fame to fall from grace and redemption-through a culture frame.

Narratives help media build images of sportspersons, sometimes leading to construction of larger-than-life profiles (Whannel, 2002), making them celebrities, role models, etc.. Panarov (2015) arrives at a conceptual framework for defining the process of creation of the media image of the sportsperson through the process of well-constructed media narratives. A set of 'occurrences' in the sportsperson's career taken up by the media content producer leads to the construction of the 'media narrative'. The narrative is defined by the desired 'frame' about the sportsperson (positive or negative). This, in turn, leads to the building of the media 'image' of the sportsperson. In this context, the work of Milner (2010) is important as it draws comparisons between traditional status systems (based on performance) and celebrity status systems in terms of image. The author posits celebrity status as a function of high mediated visibility, image and appearance (in terms of negative correlation with age and positive correlation with beauty), explicit exchange (through various forms of media for selfpromotion or financial gain), increased intimacy and influence (with the public as a result of high mediated visibility) and fashion. These dimensions could either 'make' or 'break' the image of celebrities.

There is widespread knowledge regarding the nature of heroes and celebrities and much research has been done in the field but research that connects mediated frames of hero and celebrity in the Asian sporting field remains sparse.

\section{Conceptual Framework}

The conceptual framework drew heavily for the literature reviewed and was based on the Input-ProcessOutput Model. For the Input dimension, the stages of the frame building as defined by Entman (1993) and Giles (2008) are used in this study. Cricketers from Sri Lanka and India defined the Agency or actor stage, and were chosen based on their ODI ranking by ICC in
2017 (www.icc-cricket.com). The Identification stage of framing was conceptualised within the dimensions of 'hero' and 'celebrity' frames. The Categorisation stage was defined on the basis of Hussain's (2004) conceptions of performance and character frames. Generalisation stage was defined by the context within which information is presented in each article being analysed (for example situations, attributes, choices, actions, issues and responsibility). The Narrative stage or the media style of storytelling was analysed using concepts of narrative frames as delineated from the literature review. The process dimension (considered here as the Independent variable) consisted delineating journalistic framing of news stories as conceptualised by Waller Connaway (2011) — the use of cognitive, rhetorical and ideological dimensions for frame building in the news stories on the cricketers. For the Output dimension, a list of unique and common dimensions characterising hero, celebrity, character and performance were generated from the literature reviewed and used as the basis for content analysis of the article for framing each cricketer. Low dimensions were rated as 0 and high as 1. Thus, a "high/low hero-celebrity-characterperformance classification matrix" was generated. The stages of framing-the Input-(agency, identification, categorisation, generalisation and narrative) goes through the process of media frame building by the journalist using cognitive, rhetorical and ideological dimensions that finally determines the way journalists frame the cricketer (Figure 1).

The study seeks to prove that journalistic use of cognitive, rhetorical and ideological dimensions of framing influences the portrayal of the agency (cricketer), identification as hero/celebrity, categorisation as performance or character-driven, generalisation in the context in which the frame is built and narrative style adopted by media. This, thus, results in the classification of cricketers that situates them in a high/low hero/ celebrity-performance/character matrix.

The conceptual framework defines the research question: Is the portrayal of the agency (cricketer), identification, categorisation, generalisation and narrative style influenced by journalistic use of cognitive, rhetorical and ideological dimension of framing?

\section{METHODOLOGY}

This research is an attempt to re-examine the real value of sports heroes and celebrities and the great bearing that the Indian and Sri Lankan media has in crafting them. This study primarily builds on the content analysis of selected mainstream English dailies, seeking to find out the trends in framing of Indian and Sri Lankan Cricket players. 


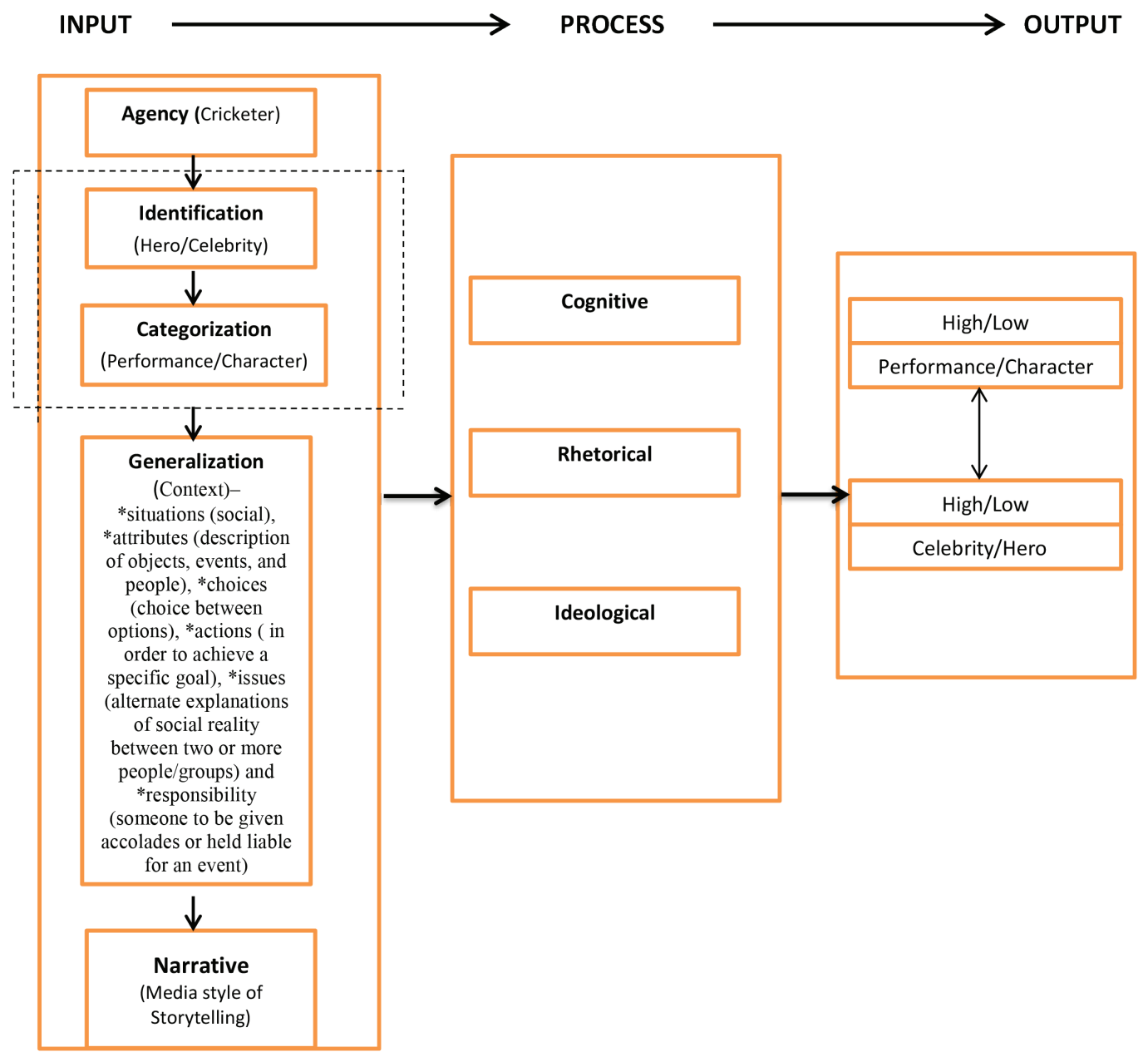

Figure 1 : The Conceptual Framework

Qualitative analysis of the content seeks to find out the nature, tone and focus of media content on cricketers within a hero vs celebrity performance/character-based matrix. Two national level English dailies i.e. the Times of India (TOI) from India and the Daily Mirror from Sri Lanka have been chosen to represent the mainstream print media. The online versions of these newspapers were chosen. The choice of the newspapers was based on the premise that they were a representative sample of highly circulated, popular newspapers, catering to different geographic regions, ideological and intellectual interests.

\section{Methods of data collection and analysis}

It was found that both newspapers had a standalone widget for cricket, presenting news stories about cricketers. The widget was searched (using the search option embedded in the online newspaper) for mentions of the cricketers' names. The cricketers selected for analysis were top batsmen who had captained matches for their respective countries-namely, Angelo Mathews and Upul Tharanga for Sri Lanka and M. S. Dhoni and Virat Kohli for India. Sri Lanka had five different captains in ODIs in 2017. After Mathews quit, Upul Tharanga was named the captain. Similarly, Dhoni quit and gave up the captaincy to Kohli. Time span of the study was 10 months from January to October 2017. During this time, the ICC Champions Trophy (5 ODIs and 3 test series) were played between the two countries. A simple random sample of 166 articles was produced. Inter-Coder Reliability Analysis was done with the use of a coding sheet. Two proficient coders were responsible for coding the data. A pilot newspaper analysis was conducted on 100 articles in order to test inter-coder reliability. All variables were 
coded for each mention of the cricketers. Cohen's kappa (K) was found to be between +1 and -1 , with significant $\mathrm{p}$ values for all variables.

\section{Measures}

From the total of 166 articles sampled, the total number of entries made under each dimension: performance/ character-hero/celebrity were analysed. In the next stage of analysis, entries under each section of the eight classes: performance/hero-high; performance/hero-low; performance/celebrity-high; performance/celebritylow; character/hero-high; character/hero-low; character/ celebrity-high and character/celebrity-low, were noted, using a set of keywords identified from the literature reviewed (Appendix). An average of each class was calculated by dividing the number of each class with the total number of articles for each player and the resultant values plotted on a graph; for e.g. M. S. Dhoni had 17 performance/hero-high entries and the average was calculated as $17 / 43$ (where 43 was the total number of articles on the TOI website that mentioned him during the time span of the study).

\section{ANALYSIS}

\section{The Input}

The analysis of the newspaper focused on the variables: Performance as a High Celebrity, Performance as a Low Celebrity, Performance as a High Hero, Performance as a Low Hero, Character as High Hero, Character as a Low Hero, Character as High Celebrity and Character as Low Celebrity, to determine the position of the selected players in a matrix.

\section{Content Analysis}

\section{Performance-Hero/High-Low}

The players are portrayed in the newspaper articles with features of High as well as Low Hero. This portrayal happens through the language and narrative techniques.

\section{S. Dhoni in Times of India (TOI)}

Example 1: In the article ' 1 st $O D I$ : Pandya, Dhoni guide India to easy win over Australia' published on $17^{\text {th }}$ September (Press Trust of India, 2017a), the sentence "Mahendra Singh Dhoni's customary calm enabled India to a comfortable win" establishes Calmness as a feature of the person, which creates a heroic image in the mind of the readers.

Example 2: Similarly, the article 'Joginder Sharma on 2007 World T20 win: I was waiting for Dhoni to give me that last over' by Abhimanyu Mathur published on $24^{\text {th }}$ September (Mathur, 2017) says that "Dhoni has surprised many with some unconventional decisions" which brings out a heroic character - 'the courage to take up responsibility' which is a prime quality in every captain.

Example 3: Dhoni's on-field achievements are highlighted with flowery words. For instance, referring to his accomplishments as the "coveted landmark" (Press Trust of India, 2017a) mentioning him as a "special player" who "still finishes games for India." Similarly, the article "All eyes on milestone man MS Dhoni as India eye fourth win' by Archiman Bhaduri published on August $31^{\text {st }}$ (Bhaduri, 2017a), invokes a feeling that only he can bring home a comfortable win.

Example 4: The article 'Spotlight on Nehra, India look to turn tables in T20s against New Zealand' published on October $31^{\text {st }}$ (Press Trust of India, 2017b) commends that "Mahendra Singh Dhoni will look to shoulder the batting responsibility."

Example 5: 'IPL GC proposal may ease Dhoni's return to Chennai Super Kings' published on October 24 ${ }^{\text {th }}$ (Press Trust of India, 2017c) is completely focused on the "anticipated return" of Dhoni to his previous IPL team. This neglects all other prospects regarding the re-birth of CSK but focuses the spotlight entirely on M. S. Dhoni.

The Rhetorical process of frame building employed by newspapers can be evidently realised from the headlines across the reports analysed which refer to M. S. Dhoni as "milestone man", "finisher at finishing line", "Dhoni is like wine, getting better with age", "wow's cops with marksmanship" etc. Similarly, there are also articles that mark the low performance of M. S. Dhoni as a hero.

Example 1: Article 'Mumbai beat Pune by one run to claim their third IPL crown' by J. A. C. Gladson, published on May 22 ${ }^{\text {nd }}$ (Gladson, 2017); the sentence "M. S. Dhoni, in his seventh final, failed to seal the deal and Mumbai made a tight fist of it" marks his low performance as a hero.

Example 2: 'Under pressure India face rare series defeat at home' published on October $24^{\text {th }}$ (Press Trust of India, 2017d) accuses Dhoni for "not capitalizing his good start".

Example 3: In article 'I am like wine: Dhoni on getting better with age' published on July $1^{\text {st }}$ (Press Trust of India, 2017e) talks about "element of inconsistency in his batting" which is a point towards his low "heroship".

Example 4: An article published on April 20 ${ }^{\text {th }}$ (Press Trust of India, 2017f) which refers to the "criticism from all 
quarters" faced by Dhoni, marked his low performance as a hero. However, within the same article, there are instances of the need to recognise him as a high hero among some-for example, the title itself-'A player like Dhoni should always be respected, says Raina’.

The agency in these articles is M. S. Dhoni, being identified as a hero, categorised within a performance frame of high/low. The contexts used here are description of his attributes ("calm") and responsibility, decision making power, shouldering the responsibility, anticipated personality, whereas some articles hold him liable for "failing to seal the deal", "resulting in the loss for his team" and mention about the "inconsistency" in his performance.

\section{Virat Kohli in TOI}

Example 1: The article 'Kohli equals Tendulkar's feat, Bumrah jumps to $4^{\text {th }}$ in ODI ranking' published on September $4^{\text {th }}$ (Press Trust of India, 2017g) is a pointer towards Virat Kohli's consistent great performance, and makes a note of his "stranglehold on the top spot in the ICC ODI batsman rankings".

Example 2: Archiman Bhaduri in his article 'India savour unprecedented whitewash' published on September $8^{\text {th }}$ appreciates Kohli-“"Wherever he is fielding, he gives it his all" and compares "Kohli's brigade with New Zealand's famous All Blacks rugby team" (Bhaduri, $2017 b$ ). This is a rhetorical frame working within the article and through great comparisons the credits moves away from the team towards Kholi.

Example 3: 'Skipper Virat Kohli's blazing blade ensured a comfortable seven-wicket win' described Kohli as "leading from the front" (Press Trust of India, 2017h).

Example 4: Statements such as "Kohli steadied the ship by beginning cautiously after India lost openers" (Bhaduri, 2017e), "Kohli adjusted his game accordingly" (Press Trust of India, 2017ad), "become the strength of the Indian team" (Press Trust of India, 2017x), from across articles in the month of October, highlight his team spirit and his major share of contribution to the team's victory. Statements like "Since Virat has come, the fitness of the team has improved a lot" (Press Trust of India, 2017i) add to his super-hero title.

Example 5: In the case of Kohli, many instances can be seen where he is deliberately given a global status which is not the case with other players. "He is a phenomenal cricketer. He is the best cricketer in the world. The way he is playing and leading from the front is fantastic", says Jhulan Goswami in his interview to TOI (Press Trust of India, 2017ae). His comparison with international players/legends from other sports happen quite often even in non-Indian newspapers; "Forget 'Bend it like Beckham'. England's cricketers are trying to 'Club it like Kohli' in a bid to get their bowlers ready for Thursday's next onslaught" writes Dean Wilson for Mirror on $17^{\text {th }}$ January (Wilson, 2017).

Further, Virat Kohli is a person with least low performance as a hero. Rarely does the media get a chance to write about his downfall or instances where he went wrong and did badly for the team. He is always an "attractive", "brilliant" and "handsome" sportsman who is the Face of Indian cricket as well as for a number of commercial products. His lowest performance from ten months was being displaced from the top spot in ranking by A. B. De Villiers "India skipper Virat Kohli has slipped a place to be at No. 2 in ODI batsmen's rankings" says the $T O I$ article titled 'AB de Villiers dislodges Virat Kohli to take top spot in ODI rankings' published on October 20 $0^{\text {th }}$ (Press Trust of India, 2017af).

\section{Angelo Mathews in Daily Mirror}

Angelo Mathews is the top Sri Lankan in ICC ODI Ranking of batsman, bowler and all-rounder. Thus, his status as a high performing hero is evident from the ranking itself. However, the media do portray him in a different angle.

Example 1: "Sri Lankan selectors have dropped former skipper Angelo Mathews" states the Daily Mirror article 'Mathews, Malinga excluded from Pakistan ODIs' published on October $4^{\text {th }}$ (Fernando, 2017a).

Example 2: His performances were often forgotten in the eagerness of the media to cover his inconsistent health. "Sri Lanka bowl first, Mathews misses out" (Daily Mirror, 2017), "Injury may keep Mathews out of CT opener" (Daily Mirror, 2017o), "Mathews to miss Bangla Tests" (Daily Mirror, 2017q) are some examples during the month of June, a time when Mathews was the only Sri Lankan to feature in the ODI Ranking.

With such an opportunity to highlight his heroic deed, the media focused on his recurring ill-fitness making him a low performing hero. Despite of continuous injuries, Mathews captained Sri Lanka for most part of the year. "The team will be led by Angelo Mathews for at least the first three games" (Daily Mirror, 2017r), "Angelo Mathews will captain the Sri Lanka team for the forthcoming ICC Champions Trophy" (Daily Mirror, 2017s), " showed glimpses of great leadership and as a cricketer by leading from the front" (Press Trust of India, 2017s) are some examples. 
Example 3: "Had Mathews played, things could have changed and we might have got the better of South Africa" writes Paulinus de S. Wijeyeratne in the article 'Will Sri Lanka be able to challenge the Indians?', making it evident that Sri Lanka is paying for the absence of its most experienced player and captain (Wijeyeratne, 2017).

Example 4: His batting skill was praised by Shehan Thomas in article 'Angelo Mathews - A man who has met with triumph and disaster' published on $15^{\text {th }}$ June 2017 (Thomas, 2017). He writes "Mathews batted with purpose and a sense of security in his controlled innings". "Angelo Mathews is the only Sri Lankan cricketer to feature in the latest ODI rankings" (Daily Mirror, 2017t), "all-rounder Angelo Mathews is the leading player among batsmen $\left(27^{\text {th }}\right)$ as well as bowlers $\left(53^{\text {rd }}\right)$ and the only all-rounder in the series among the top-five" (Daily Mirror, 2017u) are some further examples.

\section{Upul Tharanga in Daily Mirror}

Upul Tharanga is one of the best openers and 'substitute captain' for the Sri Lankan national team. His opening has helped the team with a great start at many instances.

Example 1: "The first Sri Lankan and $11^{\text {th }}$ batsman in the one-day history to carry his bat through a complete innings with a fighting" in the article 'Azam hits ton as Pakistan sink Sri Lanka', dated October 17 $7^{\text {th }}$ (Daily Mirror, 2017a).

Example 2: "Tharanga's return to the side has been impressive as he has been consistent with the bat" talks about his steadiness in article 'Chandimal, Tharanga replace Angelo' published 12 $2^{\text {th }}$ July (Fernando, 2017b). Articles 'Tharanga Century in vain as Black Caps Sri Lanka in high-scoring game' published on May $30^{\text {th }}$ (Daily Mirror, 2017b) and 'Don't rotate players too oftenUpul Tharanga' an interview of Tharanga by Champika Fernando published on $15^{\text {th }}$ May use statements like "Upul Tharanga was the star with the bat for Sri Lanka", "Tharanga still holds this record breaking stand" (Fernando, 2017c), that emphasises on his great batting. "Sri Lanka have limited-overs captain Upul Tharanga in the side", "Upul Tharanga has been appointed as the ODI and T20 captain" (Daily Mirror, 2017v), "Upul Tharanga's first series as full-time skipper" and "Upul Tharanga has been chosen to Captain Sri Lanka's five ODI matches" (ANI, 2017a) show his recurring position as a captain and highlights his ability as leader.

However, his low performances are also marked in the articles in a similar rate.
Example 1: "Tharanga had not been able to hold a regular spot in the team" is what Daily Mirror writes about him in the article 'Upul Tharanga recalled for final ODI vs. Australia' published on September $3^{\text {rd }}$ (Daily Mirror, 2016).

Example 2: His failure as a substitute captain is also a recurring frame, with the topic being repeated for over a week. "Upul Tharanga ruled out with a two-match ban for slow-rate" in article "SLC to probe Kapugedara after his decision to bat first', is an example (Daily Mirror, 2017c).

Example 3 : “...ruled himself out from Test cricket for six months to concentrate on limited-over cricket" is what Daily Mirror writes about Tharanga's decision not to play against Pakistan. This shows his lack of team spirit when media portray him as someone concentrating on personal gain, to improve alone rather than being with the team. " Regular captain Upul Tharanga, opted out of playing in Pakistan" in article "SL cricket team arrives in Lahore amid tight security' published on $29^{\text {th }}$ October is an example (Daily Mirror, 2017d).

\section{Performance-Celebrity-High/Low}

\section{S. Dhoni in TOI}

"There was a lot of anger from the fans of the great Indian keeper-bat" writes Nitin Naik in 'IPL 2017: Invisible captain Dhoni behind Pune's rise' published on May $17^{\text {th }}$ (Naik, 2017). This was during the time when Australian, Steven Smith was nominated as the captain of IPL team instead of M. S. Dhoni. His position among the public and his star value can be clearly estimated from this incident. With newspapers eager to cover the off-field life of the players, Dhoni's " super-dad and a family man" image among the public could be credited to the media. 'M. S. Dhoni's daughter stuns fans by singing Malayalam song' is an article published on October $25^{\text {th }}$, clearly out of context, but of much interest to the fans of the celebrity (Press Trust of India, 2017j).

Dhoni was on the newspapers not only for his onfield performances but for the great off-field recognition that he has won. Dhoni made headlines again when he was bestowed with an honorary rank of Lieutenant Colonel. Dwaipayan Ghosh writes "M. S. Dhoni wows cops with marksmanship" published on $21^{\text {st }}$ September (Ghosh, 2017). In the article 'Fan disrupts practice session to take selfie with Dhoni', Archiman Bhadhuri writes "Dhoni remains one of the most popular Indian cricketers in Sri Lanka" in the context of an issue of a fan's breaking entry during practice session, published on August 30 $0^{\text {th }}$ (Bhaduri, 2017c). "Mahendra Singh 
Dhoni will be remembered as the first among equals to sign an autograph for a crazy fan while he was out there batting for Jharkhand" in the article headlined "Vijay Hazare Trophy: Dhoni signs autograph while batting in middle' published on March $16^{\text {th }}$ is one more expamle (Press Trust of India, 2017k).

Dhoni's twitter handles and count of the followers often make it to the sports page. "His teammates and fans took to Twitter to wish one of the greatest captains of all time", "His daughter has about 36,000 followers on her account" are the type of news one finds for Dhoni as celebrity in the sports page. Even the leakage of M. S. Dhoni's aadhar card details made headlines. 'M. S. Dhoni's Aadhaar details leaked on Twitter, wife Sakshi complains to IT minister' (Press Trust of India, 20171). The article goes on to talk about how "a photo of M. S. Dhoni's Aadhaar application form was tweeted" by a stranger. In the span of 10 months, though Dhoni has slipped down in the hero frame, he does not have a low performance as celebrity. His personal and off-field life seemed to have been filled with positivity, or is at least what the media has brought out.

\section{Virat Kohli in TOI}

"He is the second most popular Indian personality on Facebook, only behind Indian Prime Minister Narendra Modi", in the article 'This is a bi-product of what we do on field: Virat Kohli on becoming $2^{\text {nd }}$ most followed Indian on Facebook' published on June $26^{\text {th }}$ is an example of the popularity of young Indian sensation that Virat Kohli is (Press Trust of India, 2017m). "Sole sportsperson from the country to feature among the world's 100 highest paid athletes in the latest Forbes list" (Press Trust of India, 2017ag) from the article headlined, 'Virat Kohli sole Indian in Forbes list of highest paid athletes', is the kind of news that only players like Virat Kohli can inspire in a sports page coverage. "Indian cricket phenom" is how he is described in the same article. "Kohli, who is now growing in strength and stature as the leader of a successful unit....expert, experienced, skilled.." says Press Trust of India in the article " 5 th ODI: Virat Kohli century seals 5-0 clean sweep against Sri Lanka" published on September $3^{\text {rd }}$ (Press Trust of India, 2017m).

Kohli's opinions and comments on other national teams have made headlines during the time span of study. It is almost as if his statement add validity to the other teams' credibility. Kohli's words on the Afghanistan Cricket team; "chart their own path to success without blindly following others", and his wishes for their success are showcased in the article "Virat Kohli showers praises on Afghanistan cricket team, wishes them success' published on $15^{\text {th }}$ October (Times of India, 2017c). The article 'Virat Kohli best batsman in the world: Mohammad Amir' published on July $18^{\text {th }}$ (Times of India, 2017d) is based on a twitter session report by peer and player Mohammed Amir from Pakistan, where he states "They all are ... but personally, Virat Kohli" for the question who he thinks is the best batsman in the world. Considering the tumultuous history of India with Pakistan, off and on the cricket field, Amir's statement endorses how Kohli and his talent is a bridge between two conflicting nations.

Kohli also has equal frames as a low performing celebrity, especially due to his open statements and aggressive attitude. One of the most discussed topics in media and Indian cricket during the month of June was the resignation of coach Anil Kumble. Reports say it was the result of a fallout between the captain and the coach "Skipper Kohli is responsible for Anil Kumble's ouster." in the article "To teach Virat Kohli a lesson, an engineer applies for coach's post' published on June $27^{\text {th }}$ (Press Trust of India, 2017o) is an example. The issue left a great black mark on the charisma that Kohli had around him as a leader, role model and his team spirit. "Virat Kohli "stays away" from social media, Sarfraz Ahmed "thanks" it' was an article published on June $18^{\text {th }}$ (Press Trust of India, 2017p), before the Champions Trophy final. Even with 16 million followers supporting him through social media "the Indian captain considers it as a distraction before a big match like ICC Champions Trophy" while the Pakistan captain channeled social media by "thanking" the Pakistan Team supporters. Another fall for the most looked up personality. 'Pakistani fan mocks Virat Kohli' was another headline that appeared after the Champions trophy final on June $20^{\text {th }}$ (Press Trust of India, 2017q), which clearly is a setback for the celebrated player. However, the media highlighted his "calm demeanor" that held the situation under control.

\section{Angelo Mathews in Daily Mirror}

"Missing Captain Angelo Mathews badly" is what Kumar Sangakkara writes for Daily Mirror in the article 'Timid Sri Lanka let South Africa off the hook - Sanga' published on June $5^{\text {th }}$ (Sangakkara, 2017). Though being reported repeatedly for his injury and absence, Mathews has managed to maintain a celebrity status and continuously appeared in newspaper reports. "His absence will be a major blow to the islanders" in the article 'Injury may keep Mathews out of CT opener' published on May 31 $1^{\text {st }}$ (Daily Mirror, 2017w) and "Injured captain Angelo Mathews is expected to return to Sri Lanka" in 'Update: Mathews to return this week' (Daily Mirror, 2017x) where the topic is still Mathews' injury, are examples of a player who is off-field, making it to the sports page quite often. 
"Mathews, the youngest Sri Lankan Skipper" is how the newspaper refers to him, holding a place in the hearts of his fans (Press Trust of India, 2017r). He had a great IPL auction in spite of his injuries. "Has been bought by Delhi Daredevils for Sri Lankan Rupees (SLR) 4.5 crore" writes Daily Mirror in article 'IPL: Mathews sold to Delhi Daredevils for SLR 4.5 crore' published on February $20^{\text {th }}$ (Daily Mirror, 2017y). Mathews also makes news as the brand ambassador of OPPO phones. "Meet and Greet for Angelo Mathew's Fans" in an article headlined 'OPPO fans had the unique opportunity to meet with OPPO Celebrity Brand Cricket Ambassador Angelo Mathews' was published on August $10^{\text {th }}$ (Daily News, 2017). "Angelo Mathews admitted that the ODI series defeat to Zimbabwe was one of the lowest points of his career" writes Champika Fernando for Daily Mirror in his article 'Lowest point in my career- Mathews' published on July $10^{\text {th }}$ (Fernando, 2017d).

"Angelo Mathews resigned last month", "Former skipper Angelo Mathews is not part of the squad" (Daily Mirror, 2017e) were the recurring lines in Daily Mirror regarding his inconsistency in the national team. Articles 'Roshen, Sadeera in Test squad after Mathews ruled out with injury' published on September $20^{\text {th }}$ (Daily Mirror, 2017e) and 'Uncapped Malinda, Vishwa in ODI squad' published on August $15^{\text {th }}$ (Daily Mirror, 2017f) and "Angelo Mathews was ruled out" in the article 'Tharanga to lead SL in T20 in Mathews' absence' (Daily Mirror, 2017f) are other examples. This marks his low performance as a celebrity.

\section{Upul Tharanga in Daily Mirror}

"The then 21-year-old Tharanga who stole the limelight" writes Champika Fernando in Daily Mirror article 'Don't rotate players too often- Upul Tharanga' published on May $19^{\text {th }}$ (Fernando, 2017c). Tharanga has effectively replaced Mathews in various matches. He has a decent status and reputation as a genuine player. The statement definitely showcases Tharanga's celebrity status. The article 'Coca-Cola Returns to Partner with Sri Lanka Cricket' published on July 27 $7^{\text {th }}$ (Daily Mirror, 2017h) talks about the great recognition of Tharanga as a brand ambassador ("Current captain of the ODI team Upul Tharanga as former brand ambassador of the company"). The statement "Upul Tharanga was given the limitedover captaincy- ODI and T20" shows how he was required by the team to take up the captaincy in the article 'Chronology of a cricket disaster' published on August $6^{\text {th }}$ by Champika Fernando (Fernando, 2017e). However, his recurring loss of captaincy has also resulted in a fading of his image. "Among the players who were not considered for selection is Tharanga" in the article "Thisara to lead Sri Lanka in T20s in Lahore: Pothas pulls out' published on October $21^{\text {st }}$ (Daily Mirror, 2017z) is evidence. His brand endorsement and inconsistency in captaincy had made him a high as well as a low celebrity among the cricket fans and others.

\section{Character/Hero-High/Low}

It is easier becoming a hero through one's performance, considering that performing in the game is what every cricketer has to do. The media also provides a fillip to cricketers becoming heroes, sometimes through their characters.

\section{S. Dhoni in TOI/Daily Mirror}

"Moniker of Captain Cool" is how Indian media refers to Mahendra Singh Dhoni. The article 'Joginder Sharma on 2007 World T20 win: I was waiting for Dhoni to give me that last over' by Abhimanyu Mathur reuses the term on September $24^{\text {th }}$ when Joginder Sharma was recalling India's first T-20 world cup win (Mathur, 2017). Ashish Ittyerah Joseph's article 'Dhoni is still the captain in the dressing room' published by Daily Mirror on September $3^{\text {rd }}$ (Joseph, 2017) states Suresh Raina complimenting Dhoni "More than a co-player, he's a good friend and above all, a good human being" which definitely add to his image of a hero in the mind of readers (Joseph, 2017). "A very modest and honest man. If he thinks he cannot contribute to India's cause in the World Cup, I don't think he will be there" is how Shilarze Saharoy quotes Mike Hussey in the article 'M. S. Dhoni deserves to go on his terms: Mike Hussey' published by Times of India on August $16^{\text {th }}$ (Saharoy, 2017). Many others praising Dhoni has also made it to the news. "Kohli then termed Dhoni, "a master" at identifying correct men for correct job", states the article 'We don't agree on everything but most things: Kohli on Dhoni' published in the Times of India on June $3^{\text {rd }}$ (Press Trust of India, 2017s).

"The word self-confidence is synonymous with Dhoni" writes Dwaipayan Datta for TOI in the article 'Champions Trophy: MS Dhoni the finisher at finishing line' published on May $28^{\text {th }}$ (Datta, 2017). Motivation, confidence, keeping up the team work, leadership are the ideological characters looked for in a hero and these articles attribute each of these qualities to this single person. "Form is temporary, class is permanent, M. S. is a class player" is how media supported Dhoni during his low performance periods. Tushar Dutt quotes Steve Smith in his article 'M. S. Dhoni's class is permanent: Steve Smith ' written for TOI on April $21^{\text {st }} 2017$ (Dutt, 2017). The article 'Champions Trophy would decide Dhoni's fate, says childhood coach' published by TOI on March $13^{\text {th }}$ states "Dhoni still has a sharp brain despite the drop in success ratio" (Press Trust of India, 2017t). 
"Dhoni once again drives home the fact that if there is anything that can reunite the two nations, it is cricket" is how TOI praises Dhoni's friendship with the Pakistani players in the article 'Kohli, Yuvraj and Dhoni pose for pictures with Azhar Ali's kids' published on June $20^{\text {th }}$ (Times of India, 2017a). Dhoni's relationship status with team mates and fans is a recurrent occurrence in the cricket sections of newspapers. "No one reacted as the man stopped the practice session and took a selfie with Dhoni, who then politely told him to leave" writes Archiman Bhadhuri for TOI in the article 'Fan disrupts practice session to take selfie with Dhoni' published on August 30 $0^{\text {th }}$ (Bhaduri, 2017c). "Dhoni's positive relationship with current captain", "his teammates and fans took to Twitter to wish one of the greatest captains of all time" are statements that makes clear the healthy relationship between the team and M. S. Dhoni (Times of India, 2017a; 2017b).

His low hero/character has been highlighted at times when he was referred to as an "out-of-form veteran" by Dwaipayan Datta (Datta, 2017) in his article 'Champions Trophy: M. S. Dhoni the finisher at finishing line' published in Times of India on May 28 ${ }^{\text {th }}$ " A A sombre looking Mahendra Singh Dhoni left the Feroz Shah Kotla separately" (Press Trust of India, 2017ah), "Dhoni has to score runs for himself. As a professional, he has to" (Press Trust of India, 2017u) are statements that force us to doubt his team spirit, and hence his character as a hero.

\section{Virat Kohli in TOI}

"Motivation for youngsters" writes Archiman Bhadhuri about Kohli in his article 'India savour unprecedented whitewash' published on September $8^{\text {th }}$ (Bhaduri, 2017b). "He's a role model to people and he pulls people with him" states Times of India in an article titled 'India are a ruthless side with immense work ethics: Pothas' published on September $7^{\text {th }}$ (Press Trust of India, $2017 \mathrm{v})$. The above articles published on consecutive dates highlight the character of Kohli as a role model and motivation within the ideological (ethical) frame. The cognitive frame has also found support here. "Kohli attributed the team's stupendous success in recent times to the team management's decision" states The Hindu article 'Picking right players for each formats key to success: Kohli' published on October $8^{\text {th }}$ (Press Trust of India, 2017w). This shows how he reacts to the success and attributes it to others - a cognitive frame situated within characterisation.

"His (Kohli's) attitude hasn't changed since he got into the team" a statement from the article 'Kohli's aggression has become India's strength, says Tendulkar' (Press Trust of India, 2017x) shows Kohli's consistent attitude even after achieving heights of fame and success. "I don't play for the three-figure mark, what's most important is to win the match for the team" - Kohli's statement in article 'Don't play for tons and that's why I cross it more: Kohli' on September $16^{\text {th }}$ (Press Trust of India, 2017ai) also emphasises his selfless attempts to win for the team and not to set records for himself. This also raises his status of hero with high character. Statements like "ready to take criticism on way to achieving greater glory", "ready to embrace challenges and ready to take risks... ready to even lose a few games while trying out something, Kohli said" in article "We should be ready to take risks: Virat Kohli' by Archiman Bhadhuri for TOI on August 20 $0^{\text {th }}$ (Bhaduri, 2017d) is clearly a cognitive frame that suggests how parties define risk/reward association with particular outcome.

Kohli is infamous for his bad temper, but the media manages to use it in his favour in 'Kohli's aggression has become India's strength, says Tendulkar' published on October 23 ${ }^{\text {rd }}$ (Press Trust of India, 2017x). "The current skipper feels he is the "boss" of the Indian cricket. If such is the attitude of a captain I don't think you require a coach" is how Times of India quotes cricket experts in article 'No need of a coach if Kohli thinks he is the boss: Prasanna' published on June 23 $3^{\text {rd }}$ (Press Trust of India, 2017y), which is not so much of a positive frame to Kohli's character. Kohli, though a celebrated hero is a personality who has a large amount of character defaming. Especially, during the resignation of coach Anil Kumble he had to take most of the blame. "Cricket Advisory Committee (CAC) member Sourav Ganguly said Virat Kohli's inputs were needed to make the decision and that the captain "needs to understand how coaches work" writes K . Shriniwas Rao in article "Virat Kohli must know how coaches work: Sourav Ganguly' published in Times of India on July $11^{\text {th }}$ (Rao, 2017). "Captain Virat Kohli was dominating the coach selection process" writes Gaurav Gupta for Times of India in his article 'CAC will only explain role of coach to Virat Kohli' published on July $11^{\text {th }}$ (Gupta, 2017). "Cricket Advisory Committee (CAC) would only make India skipper "understand" the role of the coach in the Indian team" he further writes. "To teach Virat Kohli a lesson, an engineer applies for coach's post" says Times of India in article 'To teach Virat Kohli a lesson, an engineer applies for coach's post' on June $27^{\text {th }}$ (Press Trust of India, 2017o).

\section{Angelo Mathews in Daily Mirror}

"He's not a 'know it all' and is open to seek the input of others" writes Shehan Thomas for Daily Mirror 
(Thomas, 2017) in his article 'Angelo Mathews - A man who has met with triumph and disaster...' published on June $15^{\text {th }}$. 'Angelo jokes about Sanga's comeback' is an article published in Daily Mirror on June $8^{\text {th }}$ (Daily Mirror, 2017i), where Mathews expresses "that he wished his former captain Kumar Sangakkara was in the team" which comes under the cognitive frame of a reacting to one's contemporaries and peers. "Sri Lankan captain Angelo Mathews spoke about the need for his team to be mentally tough when they meet South Africa" shows how Mathews utilises his pep talk with the team to motivate them (Daily FT, 2017).

His recurring injuries have been a reason for his negative character framing as a hero by the media. "Mathews is the key performer in the current side but a series of injuries kept him away from cricket for a significant period of time" writes Daily Mirror in the article 'Mathews steps down as captain' published on July $11^{\text {th }}$ (Daily Mirror, 2017j). "Mathews has had a history of injuries" (Daily Mirror, 2017k), "Mathews missed a number of international assignments this year" (Daily Mirror, 20171) are the statements from different articles published during September when Sri Lanka was playing an important series with Pakistan, which clearly diminishes his character as a personality, not approachable in the times of need. "He was under tremendous pressure since the South African series where his tactics were questioned" says Champika Fernando in article 'Chronology of a cricket disaster' from Daily Mirror published on August $6^{\text {th }}$ (Fernando, 2017e), which also does not uplift his character as an ideal hero.

\section{Upul Tharanga in Daily Mirror}

"Ruled himself out from Test cricket for six months" is what Tharanga did to concentrate on limited-over cricket. This is of course personal discretion to go under a positive hero character or negative character in abandoning the team. However, this line from article 'Lankans move to UAE still looking for answers' published by Daily Mirror on September $24^{\text {th }}$ (Daily Mirror, 2017aa) will give the readers an insight to his personal character. "Would take the blame for the defeats but will not quit from the captaincy" is how Daily Mirror quotes Tharanga in the article 'Tharanga says he won't quit despite whitewash' published on October $23^{\text {rd }}$ (Daily Mirror, 2017m). This definitely gives a boost to his leadership quality valued by the readers.

"Skipper Tharanga says his charges are determined to reverse fortunes during the ODI series and urged everyone to rally behind the team" is another line from Daily Mirror article 'Dhawan, Kohli lead Sri Lanka rout' published on August 20 ${ }^{\text {th }}$ (Daily Mirror, 2017n), again a highlight on his leadership quality. The ban and the fine charged on Tharanga as a captain "Upul Tharanga who was serving a two-match suspension for slow-overate" (Daily Mirror, 2017ab), "Regular skipper Upul Tharanga received a two-match ban for a serious violation" (Daily Mirror, 2017ac) all point towards his failure as a captain and thereby, a lack of the characteristic quality as a leader.

The accendence in character is more important for the heroic image than the performance factor. The matrix shows that both Virat Kohli and M. S. Dhoni as high hero in terms of character followed by Upul Tharanga, who though a high hero, is equally high in the low hero scale. Here again Angelo Mathews makes a dip as a low hero. What is evident is that despite being a high character hero (0.34), Virat Kohli has also been framed as a low character hero $(0.13)$. What is interesting is that among all four players, Angelo Mathews seems to be framed equally as high and low character hero the highest character hero. Tharanga is having less negativity (0.12).

\section{Character/Celebrity-High/Low}

Media has taken a great interest not only on the performance and the on-field activities of the cricketers but on their personal life, character and its influence on the present generation is not negligible.

\section{S. Dhoni in TOI}

"India's most successful captain" in Times of India article 'BCCI nominates MS Dhoni for Padma Bhushan award' published on September 20 ${ }^{\text {th }}$ (Press Trust of India, 2017z) has his high character as hero highlighted. "Passed out long back but his legacy has become a driving force for children" is what an article about M. S. Dhoni and his school writes for Times of India; the article is titled 'Dare are to dream, a mantra learnt from 'alumni' Dhoni' and was published on October $10^{\text {th }}$ (Press Trust of Asia, 2017aa). The article further carries how Dhoni, even after passing out, has been an inspiration in the life of students who study there today. "Dhoni embraced the city of Chennai and the fans were more than happy to oblige" statement from the article "Srinivasan hopes MS Dhoni will be back to lead CSK next season' written by Prasad R. S. and published by Times of India on April $1^{\text {st }}$ (Prasad, 2017) shows how a player from north India is widely accepted and appreciated by the crowd of Chennai. Dhoni himself has expressed his love for this southern city which increases his character value. Similarly, "Dhoni was seen holding Pakistan skipper Sarfraz Ahmed's son" was the content of article 'Kohli, Yuvraj and Dhoni pose for pictures with Azhar Ali's kids' published by Times of India on June $20^{\text {th }}$ (Times of India, 2017a). Here again the player bridges the gap 
between two countries in constant conflict by showing his friendship as a positive thing.

Vinita Chaturvedi's article (Chathurvedi, 2017) 'Meet MS Dhoni, the super dad!' published in Times of India on June $9^{\text {th }}$ mentions "He is the popular choice as the best daddy of India's cricketing horizon", clearly showing that he has achieved his hero status with his character of the field. 'Vijay Hazare Trophy: Dhoni signs autograph while batting in middle' is an article published by Times of India on March $16^{\text {th }}$ (Press Trust of India, $2017 \mathrm{k}$ ) regarding the issue of a fan breaking to the ground when the game was in progress. "Not only did he show humility but also doused what could have been a potentially volatile situation if he would have got angry" is how the article defines Dhoni's reaction to this event clearly lifting his image in the view of the readers. This doesn't mean he was resistant to the criticism on weak character. His resignation and reaction to the questions of resignation has made the headlines quite a few times. "Inconsistent form over the past year has led to debates if Dhoni is still a potent match-winner" is what Times of India writes in article 'Dhoni need not prove anything to anyone: Shane Warne' published on April 18 ${ }^{\text {th }}$ (Press Trust of India, 2017aj).

\section{Virat Kohli in TOI}

"His intention is to set the right example for his young fans" writes Indranil Basu for Times of India in the article 'Kohli wants to set right example for young fans' published on September 17 $7^{\text {th }}$ (Basu, 2017a). This was the constant attempt from the media to frame Kohli as a character and performance model for the youngsters and many more articles can be added to this list.

Kohli's emotional words and praise for his team have always made it to the news, lifting him up as a man of team spirit, loyalty and friendship. 'You will always be our captain: Kohli on Dhoni playing 300 ODIs' (Press Trust of India, 2017ak) is an article which focuses on Kohli's statement "You will always be our captain," is what an emotional Virat Kohli said." In spite of replacing Dhoni as the new captain, the attachment and unity between the two players provides light to their positivity in character. Kohli has never showed any reservation to praise good performance which is his character highlighted by the newspapers. The article 'Picking right players for each formats key to success: Kohli' published by Times of India on October $8^{\text {th }}$ (Press Trust of India, 2017w) he "praised his new ball bowlers" and his " 15 -second video on his official Twitter handle" praising Under-17 football team of India was the content of the article 'Good luck boys and make us proud, Kohli tells India U-17 football team' published on October $2^{\text {nd }}$ (ANI, 2017b).
Kohli is also a social figure through the endorsement of various brands and most of these brands sell his character along with his performance. Young, aggressive and hardworking is a label under which the brand Virat Kohli goes. "Kohli currently endorses 17 brands- all carefully chosen keeping in mind his social connect" writes article 'To practice what he preaches, Kohli drops Pepsi, fairness products' published in Times of India on September $16^{\text {th }}$ (Press Trust of India, 2017ab), about Kohli's ethics as a celebrity endorser. "Captain Virat Kohli has stopped endorsing soft drink maker Pepsi and fairness products because of their association with junk food and racism" explains the article, clearly uplifting the social image of the personality. "It is not about money here. He didn't want to be a brand ambassador of something which he doesn't use in real life. Kohli knows there are plenty of children who look up to him" writes Indranil Basu in the article 'Kohli wants to set right example for young fans' published on $17^{\text {th }}$ September (Basu, 2017a).

There are also instances from the newspaper that characterises him as a hero of low character. For instance, his fall out with the coach Anil Kumble was taken up by the media and portrayed more as a fault from his side. "Left vacant by Anil Kumble after fallout with Kohli" writes Times of India in article 'Virat Kohli expects no added pressure on working with Ravi Shastri' published on July $19^{\text {th }}$ (Press Trust of India, 2017ac). His alleged association with businessman Vijay Mallya, wanted by Indian government also led to his negative portrayal in the media. Article 'Why did Virat Kohli charity event team overlook Vijay Mallya's name?' published in Times of India on $10^{\text {th }}$ June (Basu, 2017b) writes "Virat Kohli Foundation's charity ball held in London on June $5^{\text {th }}$ had strangely overlooked the fact that Vijay Mallya's name figured in the list of 'hosts"'. The article has added "Mallya's presence forced the Indian players to leave the venue in a hurry" defaming the name that India captain enjoys.

\section{Angelo Mathews in Daily Mirror}

"Angelo Mathews relinquishing his duties as national skipper" writes Champika Fernado in the article 'Chronology of a cricket disaster' published by Daily Mirror on August $6^{\text {th }}$ (Fernando, 2017e). He is always regarded as a team spirited leader of the national team which faced a lot of setbacks in the year of 2017. In article 'No one expected us to win: Mathews' published in Daily Mirror on June $9^{\text {th }}$ (Daily Mirror, 2017ad), Mathews represents the feelings of his entire team and their ecstasy on the win just as any other person. His down to earth character has given him a great boost among his fans. "It was very pleasing for us to give them 
a win because we had some terrible times in the recent past" is what he feels about the victory. However, he is not a celebrity beyond this point and thus, his character as a celebrity is not what the media is focusing at.

\section{Upul Tharanga in Daily Mirror}

Tharanga also has less reputation as a high character celebrity, yet his positivism has been made it to the media in an attempt of this. Daily Mirror article 'Mathews to bowl during ODI's' published on August $16^{\text {th }}$ writes "Upul Tharanga said Sri Lanka should move on from the embarrassing defeat" (Daily Mirror, 2017ae), which shows a captain's way of bringing the team spirit back from continuous defeats.

\section{Process}

Overall, the narrative frame adopted by Times of India is more explicit than that of the Daily Mirror in terms of Cognitive, Rhetorical and Ideological frame building process (Figure 2). TOI has also made a deeper dive into the personal lives of the players when compared to Daily Mirror, even attempting to give the "Super Dad" title to Mahendra Singh Dhoni and making Kohli a verb; "Kohlied".

Daily Mirror has sometimes purposefully highlighted the brand status of the player and brought it up as a news item when their players were under a threat of losing their stardom. The TOI narrative style is more flowery while Daily Mirror tries to authenticate its news with more quotes from experts. The ten months of the survey has been incidentally, a more of negative time for Sri Lankan players compared to the star value and victories enjoyed by their Indian counterparts. The personal life of M. S. Dhoni has made its maximum to the cricket session, while Kohli's brand endorsements-related news also made it to the sports page. It was the unpredictable injury for captain Mathews that overshadowed his ODI ranking achievements in the newspapers, while Tharanga repeatedly appeared as a substitute captain and was indirectly blamed for his lack of leadership abilities.

\section{The Output}

Figures 3 and 4 show the comparative averages for the four players for the dimensions:

It is evident Kohli has the highest PerformanceHero frame among the four players. He seems to be the media's blue-eyed boy, with very few instances of a low heroic performance frame. For the Celebrity Performance frame, it is Dhoni who leads. He has been given weightage both as a high and low Heroic Performer (0.36 and 0.26). Tharanga seems to match Kohli as a high heroic performer and also shares the high celebrity performer frame with him. Overall, both are higher hero than celebrity performers. Mathews leads as the low hero performer. Both Kohli and Dhoni seem to be high in the heroic and celebrity character frames, with Kohli having an edge over Dhoni. Mathews and Tharanga seem not so much celebrity characters, as they are heroic characters. Mathews scores the lowest as heroic character among all four players.

\section{CONCLUSION}

The study reveals the comparative focus of Times of India and Daily Mirror in terms of attention given to Indian and Sri Lankan cricketers, respectively, and placing them

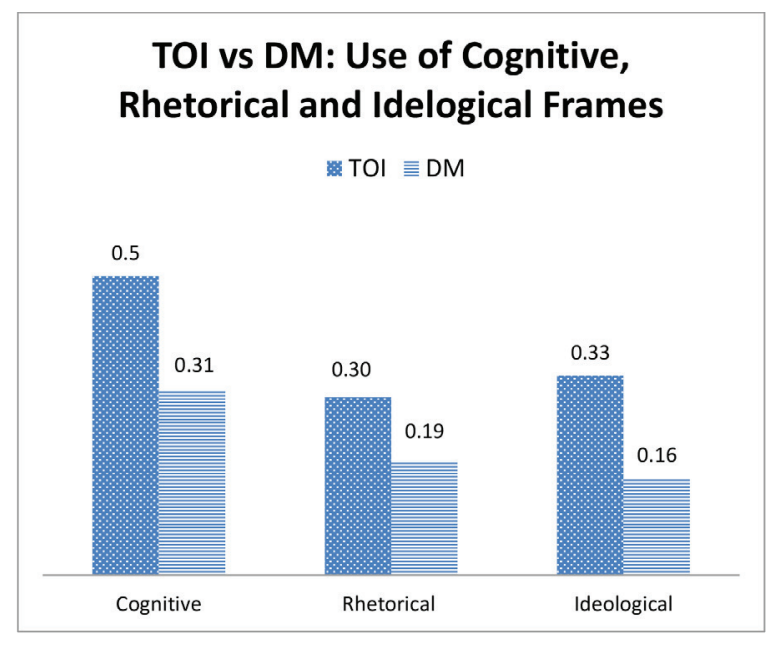

Figure 2: Times of India (TOI) vs Daily Mirror (DM): Use of Cognitive, Rhetorical and Ideological Frames 


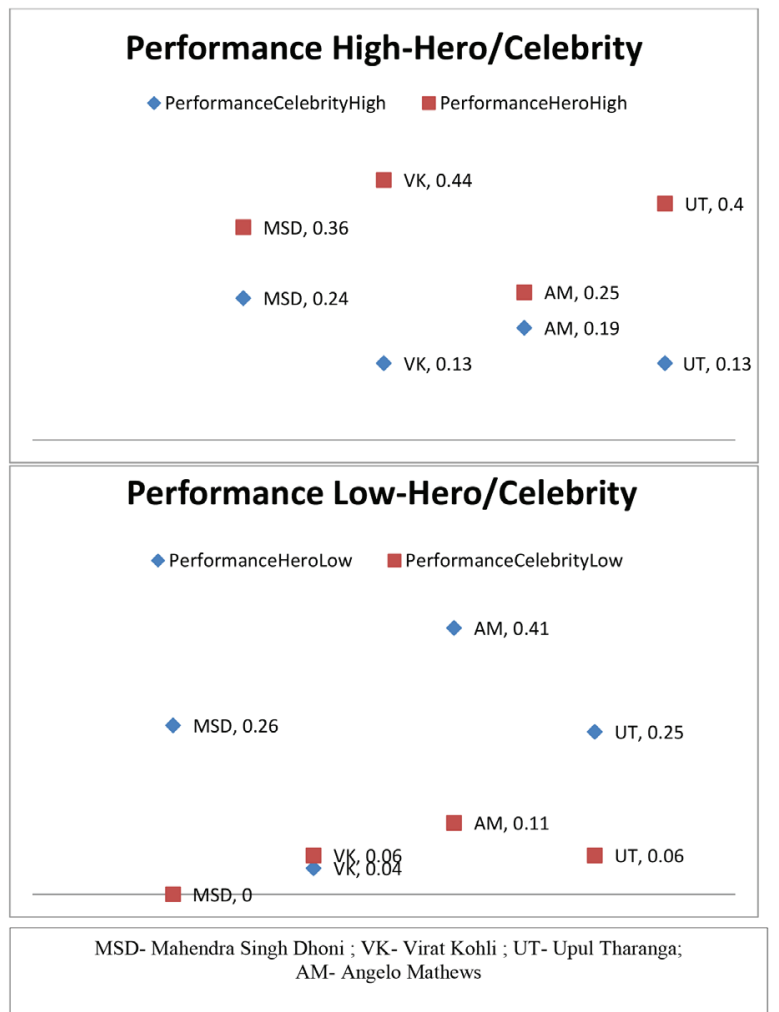

Figure 3: Comparative averages for the four players for the dimension Performance (High/Low)-Hero/Celebrity

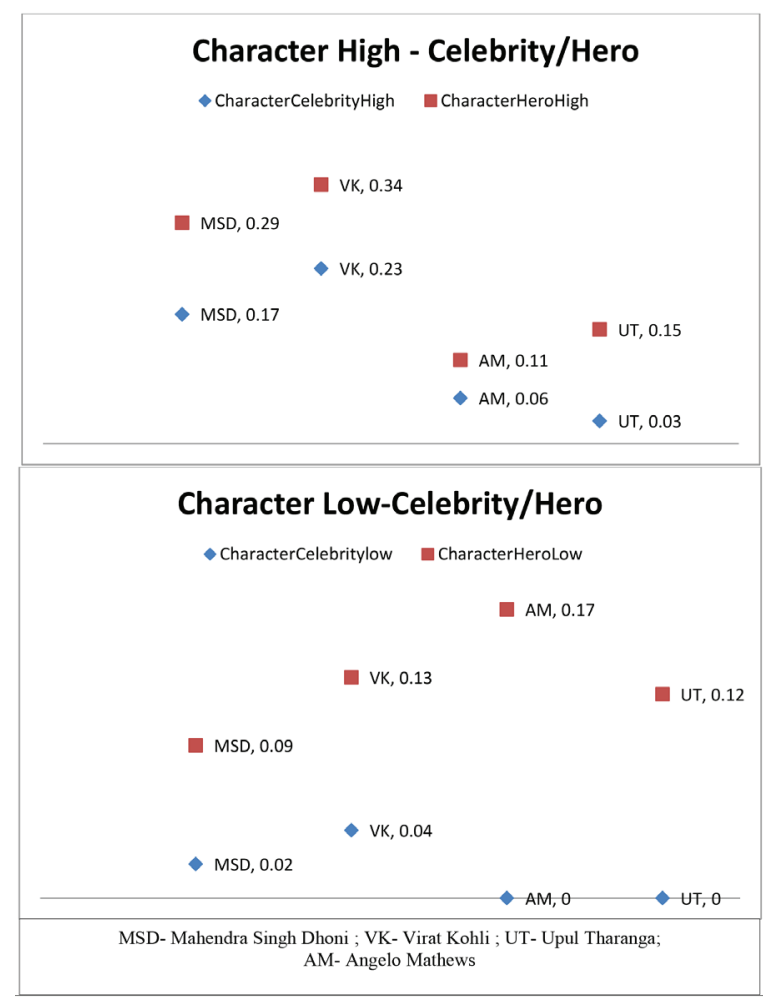

Figure 4: Comparative averages for the four players for the dimension Character (High/Low)-Hero/Celebrity 
within a hero/celebrity-performance/character matrix using a cognitive, rhetorical and ideological frame building process. Thus, these newspapers can influence readers' perceptions of cricketers as heroes or celebrities by highlighting their characters or performance positively or negatively. The study shows how popular mainstream print media habitually reduce the team sport of cricket into a competition between individual players (by highlighting their heroic or celebrity appeal through performance or character). These sporting individuals, methodically contrived as iconic figures are able to echo cultural and social sensibilities.

\section{LIMITATIONS}

Newspapers were the only form of media used for this study. Future research might include other forms of media such as radio, magazines, television, news transcripts or online news sources for a comparative study. A longitudinal study would also reveal patterns of change over time in the frame building process.

\section{REFERENCES}

ANI (2017a) Upul Tharanga to captain Sri Lanka in ODIs against South Africa, ANI [Online] 25 $5^{\text {th }}$ January, Available from: https://www.india.com/sports/upul-tharanga-to-captainsri-lanka-in-odis-against-south-africa-1781257/ [Accessed: 6th September 2018].

ANI (2017b) FIFA U-17 World Cup- Good luck boys, make us proud, Kohli tells Indian Colts, ANI [Online] $2^{\text {nd }}$ October, Available from: https://www.aninews.in/news/sports/football/ fifa-u-17-world-cup-good-luck-boys-make-us-proud-kohlitells-indian-colts201710021935140005/ [Accessed: $6^{\text {th }}$ September 2018].

Basu, I. (2017a) Kohli wants to set right example for young fans, Times of India [Online] $17^{\text {th }}$ September, Available from: https://timesofindia.indiatimes.com/sports/cricket/australiain-india/kohli-wants-to-set-right-example-for-young-fans/ articleshow/60716593.cms [Accessed: $6^{\text {th }}$ September 2018].

Basu, I. (2017b) Why did Virat Kohli charity event team overlook Vijay Mallya's name?, Times of India [Online] $10^{\text {th }}$ June, Available from: https://timesofindia.indiatimes.com/ sports/cricket/news/why-did-virat-kohli-charity-event-teamoverlook-vijay-mallyas-name/articleshow/59080582.cms [Accessed: $6^{\text {th }}$ September 2018].

Bateson, G. (1972) Steps to an ecology of mind: Collected essays in anthropology, psychology, evolution and epistemology, San Francisco, California: Chandler, pp: 447-454.

Beck, D. and Bosshert, L. (2003) Sports and Media, Communication Research Trends, 22 (4), pp: 1-43.
Berg, L. R. V. (1998) 'The sports hero meets mediated celebrityhood' In Wenner, L. A. (ed.) Media Sport, London and New York: Routledge, pp: 134-153.

Bhaduri, A. (2017a) All eyes on milestone man MS Dhoni as India eye fourth win, Times of India [Online] $31^{\text {st }}$ August, Available from: https:/timesofindia.indiatimes.com/sports/ cricket/india-in-sri-lanka/all-eyes-on-milestone-man-msdhoni-as-india-eye-fourth-win/articleshow/60301877.cms [Accessed: $6^{\text {th }}$ September 2018].

Bhaduri, A. (2017b) India savour unprecedented whitewash, Times of India [Online] $8^{\text {th }}$ September, Available from: https://timesofindia.indiatimes.com/sports/cricket/indiain-sri-lanka/india-savour-unprecedented-whitewash/ articleshow/60418169.cms [Accessed: $13^{\text {th }}$ November 2017].

Bhaduri, A. (2017c) Fan disrupts practice session to take selfie with Dhoni, Times of India [Online] 30 ${ }^{\text {th }}$ August 2017, Available from: https:/timesofindia.indiatimes.com/sports/ cricket/india-in-sri-lanka/fan-disrupts-practice-session-totake-selfie-with-dhoni/articleshow/60286007.cms [Accessed: $7^{\text {th }}$ September 2018].

Bhaduri, A. (2017d) We should be ready to take risks: Virat Kohli, Times of India [Online] 20 $0^{\text {th }}$ August, Available from: https://timesofindia.indiatimes.com/sports/cricket/indiain-sri-lanka/we-should-be-ready-to-take-risks-virat-kohli/ articleshow/60140350.cms [Accessed: $5^{\text {th }}$ February 2017].

Bhaduri, A. (2017e) Virat Kohli magic ensures team return unbeaten from Sri Lanka, Times of India [Online] $7^{\text {th }}$ September, Available from: https:/timesofindia.indiatimes.com/sports/ cricket/india-in-sri-lanka/virat-kohli-magic-ensures-teamreturns-unbeaten-from-sri-lanka/articleshow/60401750.cms [Accessed: $6^{\text {th }}$ September 2018].

Bolognani, M. (2011) Star fission: Shoaib Akhtar and fragmentation as transnational celebrity strategy, Celebrity Studies, 2(1), pp. 31-43 [Online] Available from: https://www. researchgate.net/publication/233164158_Star_fission_Shoaib_ Akhtar_and_fragmentation_as_transnational_celebrity_ strategy [Accessed: $13^{\text {th }}$ October 2017].

Boorstin, D. J. (1978) The republic of technology: reflections on our future community, New York: Harper \& Row.

Boyle, R. and Haynes, R. (2009) Powerplay: Sport, the Media and Popular Culture (II Ed.) Edinburgh: Edinburgh University Press.

Brown, J. W. (2010) Steve Irwin's influence on wildlife conservation, Journal of Communication, 60(1), pp: 73-93.

DOI: https://doi.org/10.1111/j.1460-2466.2009.01458.x

Bryson, L. (1987) Sport and the maintenance of masculine hegemony, Women's Studies International Forum, 10, pp: 349360 .

DOI: https://doi.org/10.1016/0277-5395(87)90052-5 
Bull, A. (2015) Kumar Sangakkara: Not many compare to Sri Lanka's Selfless Statesman, The Spin: The Guardian [Online] $30^{\text {th }}$ June, Available from: https:/www.theguardian.com/ sport/2015/jun/30/the-spin-kumar-sangakkara [Accessed: $21^{\text {st }}$ October 2017].

Business Standard (2017) I don't play for centuries that's why I cross it more: Virat Kohli", Business Standard [Online] $16^{\text {th }}$ September, Available from: https://www.business-standard. com/article/current-affairs/i-don-t-play-for-centuries-thats-why-i-cross-it-more-virat-kohli-117091600577_1.html [Accessed: 18 ${ }^{\text {th }}$ January 2018].

Chalip, L. (1997) Celebrity or hero? toward a conceptual framework for athlete promotion, advancing management of Australian and New Zealand sport, Melbourne, Victoria: SMAANZ.

Chaturvedi, V. (2017) Meet M S Dhoni the super dad, Times of India [Online] $11^{\text {th }}$ July, Available from: https://timesofindia. indiatimes.com/life-style/spotlight/ms-dhoni-is-a-super-dad/ articleshow/59075252.cms [Accessed: $6^{\text {th }}$ September 2018].

Clarke, A. and Clarke, J. (1982) Highlights and action replays'Ideology, sport, and the media, In J. Hargreaves (Ed.) Sport, culture, and ideology, pp: 62-87, London: Routledge \& Kegan Paul.

Critcher, C. (1979) Football Since The War, In J. Clarke, C. Critcher \& R. Johnson (Eds.) Working-class Culture: Studies in history and theory, pp: 161-184, London: Hutchinson of London.

Daily FT (2017) Sri Lanka ponder changes for second Test, Daily FT [Online] $2^{\text {nd }}$ January, Available from: http://www.ft.lk/ sports/sri-lanka-ponder-changes-for-second-test/23-588562 [Accessed: $4^{\text {th }}$ May 2018].

Daily Mirror (2016) Upul Tharanga recalled for final ODI vs. Australia, Daily Mirror [Online] $3^{\text {rd }}$ September, Available from: http://www.dailymirror.lk/115210/Upul-Tharanga-recalledfor-final-ODI-vs-Australia [Accessed: $4^{\text {th }}$ May 2018].

Daily Mirror (2017a) Azam hits ton as Pakistan sink Sri Lanka, Daily Mirror [Online] 16 ${ }^{\text {th }}$ October, Available from: http:// www.dailymirror.lk/article/Sri-Lanka-one-batsman-shortTharanga-138526.html [Accessed: $5^{\text {th }}$ November 2017].

Daily Mirror (2017aa) Lankans move to UAE still looking for answers, Daily Mirror [Online] $24^{\text {th }}$ September, Available from: http:/www.dailymirror.lk/cricket-news/Lankans-moveto-UAE-still-looking-for-answers/320-137202 [Accessed: $4^{\text {th }}$ May 2018].

Daily Mirror (2017ab) Will assess future after series- Malinga, Daily Mirror [Online] $1^{\text {st }}$ September, Available from: http:// www.dailymirror.lk/cricket-news/Will-assess-future-after-theseries-Malinga/320-135811 [Accessed: $4^{\text {th }}$ May 2018].
Daily Mirror (2017ac) Lasith Malinga to lead Sri Lanka in fourth ODI, Daily Mirror [Online] 29 ${ }^{\text {th }}$ August, Available from: http://www.dailymirror.lk/cricket-news/Lasith-Malinga-tolead-Sri-Lanka-in-fourth-ODI/320-135579 [Accessed: $4^{\text {th }}$ May 2018].

Daily Mirror (2017ad) No one expected us to win: Mathews, Daily Mirror [Online] $9^{\text {th }}$ June, Available from: http://www. dailymirror.lk/130564/No-one-expected-us-to-win-Mathews [Accessed: $4^{\text {th }}$ May 2018].

Daily Mirror (2017ae) Mathews to bowl during ODIs, Daily Mirror [Online] 16 ${ }^{\text {th }}$ August, Available from: http:// www.dailymirror.lk/cricket-news/Mathews-to-bowl-duringODI-s/320-134851 [Accessed: $4^{\text {th }}$ May 2018].

Daily Mirror (2017b) Tharanga century in vain as Black Caps Sri Lanka in high-scoring game, Daily Mirror [Online] $30^{\text {th }}$ May, Available from: http://www.dailymirror.lk/cricket-news/ Tharanga-century-in-vain-as-Black-Caps-Sri-Lanka-in-highscoring-game/320-129912 [Accessed: $7^{\text {th }}$ September 2017].

Daily Mirror (2017c) SLC to probe Kapugedara after his decision to bat first, Daily Mirror [Online] $30^{\text {th }}$ August, Available from: http://www.dailymirror.lk/cricket-news/SLC-to-probeKapugedara-after-his-decision-to-bat-first/320-135607 [Accessed: $4^{\mathrm{h}}$ May 2018].

Daily Mirror (2017d) SL cricket team arrives in Lahore amid tight security, Daily Mirror [Online] 29 ${ }^{\text {th }}$ October, Available from: http://www.dailymirror.lk/139351/SL-cricket-teamarrives-in-Lahore-amid-tight-security [Accessed: $4^{\text {th }}$ May 2018].

Daily Mirror (2017e) Roshen, Sadeera in test squad after Mathews rules out with injury, Daily Mirror [Online] $20^{\text {th }}$ September, Available from: http://www.dailymirror.lk/article/ Roshen-Sadeera-in-Test-squad-after-Mathews-ruled-out-withinjury--137000.html?fbrefresh $=1505934607 \quad$ [Accessed: $4^{\text {th }}$ May 2018].

Daily Mirror (2017f) Uncapped Malinda, Vishwa in ODI squad", Daily Mirror [Online] 15 $5^{\text {th }}$ August, Available from: http://www.dailymirror.lk/cricket-news/Uncapped-MalindaVishwa-in-ODI-squad/320-134758 [Accessed: $4^{\text {th }}$ May 2018].

Daily Mirror (2017g) Tharanga to lead SL in T20 in Mathews' absence, Daily Mirror [Online] $3^{\text {rd }}$ April, Available from: http:// www.dailymirror.lk/cricket-news/Tharanga-to-lead-SL-in-Tin-Mathews-absence/320-126693 [Accessed: $4^{\text {th }}$ May 2018].

Daily Mirror (2017h) Coca-Cola returns to partner with Sri Lanka cricket, Daily Mirror [Online] $27^{\text {th }}$ July, Available from: http://www.dailymirror.lk/cricket-news/Tharanga-to-lead-SLin-T-in-Mathews-absence/320-126693 [Accessed: 4 ${ }^{\text {th }}$ May 2018].

Daily Mirror (2017i) Angelo jokes about Sanga's comeback, Daily Mirror [Online] $8^{\text {th }}$ June, Available from: http:// 
www.dailymirror.1k/article/Angelo-jokes-about-Sanga-scomeback-130488.html [Accessed: $4^{\text {th }}$ May 2018].

Daily Mirror (2017j) Mathews steps down as captain, Daily Mirror [Online] 11 ${ }^{\text {th }}$ July, Available from: http:// www.dailymirror.1k/article/Mathews-steps-down-ascaptain--132606.html [Accessed: $4^{\text {th }}$ May 2018].

Daily Mirror (2017k) Injured Mathews likely to miss second Test, Daily Mirror [Online] 11 ${ }^{\text {th }}$ October, Available from: http:// www.dailymirror.lk/cricket-news/Injured-Mathews-likely-tomiss-second-Test/320-137573 [Accessed: $4^{\text {th }}$ May 2018].

Daily Mirror (20171) Mathews to miss first Test against Pakistan with calf injury, Daily Mirror [Online] $20^{\text {th }}$ September, Available from: http://www.dailymirror.lk/cricket-news/Mathews-tomiss-first-Test-against-Pakistan-with-calf-injury/320-136976 [Accessed: $4^{\text {th }}$ May 2018].

Daily Mirror (2017m) Tharanga says he won't quit despite whitewash, Daily Mirror [Online] 24 $4^{\text {th }}$ October, Available from: http://www.dailymirror.lk/139080/Tharanga-says-hewon-t-quit-despite-whitewash [Accessed: $4^{\text {th }}$ May 2018].

Daily Mirror (2017n) Dhawan, Kohli lead Sri Lanka rout, Daily Mirror [Online] 20 $0^{\text {th }}$ August, Available from: http://www. dailymirror.lk/135010/Dhawan-Kohli-lead-Sri-Lanka-rout [Accessed: $4^{\text {th }}$ May 2018].

Daily Mirror (2017o) Sri Lanka bowls first, Mathew misses out, Daily Mirror [Online] $3^{\text {rd }}$ June, Available from: http://www. dailymirror.1k/cricket-news/Sri-Lanka-bowl-first-Mathewsmisses-out/320-130182 [Accessed: $4^{\text {th }}$ May 2018].

Daily Mirror (2017p) Injury may keep Mathews out of CT opener, Daily Mirror [Online] 1 1 June, Available from: http:// www.dailymirror.lk/130042/Injury-may-keep-Mathews-outof-CT-opener [Accessed: $4^{\text {th }}$ May 2018].

Daily Mirror (2017q) Mathews to miss Bangla Tests, Daily Mirror [Online] 25 $5^{\text {th }}$ February, Available from: http://www. dailymirror.lk/article/Mathews-to-miss-Banga-Tests-124480. html [Accessed: $4^{\text {th }}$ May 2018].

Daily Mirror (2017r) Mathews to lead SL against Zimbabwe, Daily Mirror [Online] 17 $7^{\text {th }}$ June, Available from: http://www. dailymirror.lk/cricket-news/Mathews-to-lead-SL-againstZimbabwe-/320-131088 [Accessed: $4^{\text {th }}$ May 2018].

Daily Mirror (2017s) Mathews captain for SL team for Champions Trophy, Daily Mirror [Online] 24 $4^{\text {th }}$ April, Available from: http://www.dailymirror.lk/breaking_news/Mathewscaptain-of-SL-team-for-Champions-Trophy/108-127650 [Accessed: $4^{\text {th }}$ May 2018].

Daily Mirror (2017t) Mathews only Sri Lankan to feature in latest rankings, Daily Mirror [Online] $30^{\text {th }}$ May, Available from: http:/www.dailymirror.lk/cricket-news/Mathews-only-SriLankan-to-feature-in-latest-rankings/320-129901 [Accessed: $4^{\text {th }}$ May 2018].
Daily Mirror (2017u) Sri Lanka must win two matches against India for direct World Cup entry, Daily Mirror [Online] $18^{\text {th }}$ August, Available from: http://www.dailymirror.lk/cricketnews/Sri-Lanka-must-win-two-matches-against-India-fordirect-World-Cup-entry-/320-134994 [Accessed: 4 ${ }^{\text {th }}$ May 2018].

Daily Mirror (2017v) Chandimal Test captain, Tharanga ODI and T20 captain, Daily Mirror [Online] 12 $2^{\text {th }}$ July, Available from: http://www.dailymirror.lk/132644/Chandimal-Testcaptain-Tharanga-ODI-and-T-captain [Accessed: $4^{\text {th }}$ May 2018].

Daily Mirror (2017w) Injury may keep Mathews out of CT opener, Daily Mirror [Online] 31 ${ }^{\text {st }}$ May, Available from: http:// www.dailymirror.lk/article/Injury-may-keep-Mathews-out-ofCT-opener--130008.html [Accessed: $4^{\text {th }}$ May 2018].

Daily Mirror (2017x) Update: Mathews to return this week, Daily Mirror [Online] 23 ${ }^{\text {rd }}$ January, Available from: http:// www.dailymirror.lk/122578/Update-Mathews-to-return-thisweek [Accessed: $4^{\text {th }}$ May 2018].

Daily Mirror (2017y) IPL: Mathews sold to Delhi Daredevils for SLR 4.5 crore, Daily Mirror [Online] $20^{\text {th }}$ February, Available from: http://www.dailymirror.lk/article/IPL-Mathews-sold-toDelhi-Daredevils-for-SLR-crore-124100.html [Accessed: $4^{\text {th }}$ May 2018].

Daily Mirror (2017z) Thisara to lead Sri Lank in T20s in Lahore: Pothas pulls out, Daily Mirror [Online] $21^{\text {st }}$ October, Available from: http:/www.dailymirror.lk/cricket-news/Thisara-to-leadSri-Lanka-in-T-s-in-Lahore-Pothas-pulls-out-/320-138940 [Accessed: $4^{\text {th }}$ May 2018].

Daily News (2017) OPPO fans meet Brand Ambassador Angelo Mathews, Daily News, $10^{\text {th }}$ August.

Datt, T. (2017) MS Dhoni's class is permanent: Steve Smith, Times of India [Online] 21 $1^{\text {st }}$ April, Available from: https:// timesofindia.indiatimes.com/sports/cricket/ipl/top-stories/msdhonis-class-is-permanent-steve-smith/articleshow/58303855. cms [Accessed: $18^{\text {th }}$ January 2018].

Datta, D. (2017) Champions Trophy: MS Dhoni the finisher at finishing line, Times of India [Online] $28^{\text {th }}$ May, Available from: https://timesofindia.indiatimes.com/sports/cricket/ champions-trophy-2017/top-stories/ms-dhoni-the-finisher-atthe-finishing-line/articleshow/58877181.cms [Accessed: $18^{\text {th }}$ January 2018].

de Vreese, C. H. (2005) News framing: Theory and typology, Information Design Journal + Document Design, 13(1), pp: 5162, Amsterdam: John Benjamins Publishing Company [Online] Available from: https://msap-unlam.ac.id/download/bahan bacaan/New\%20Framing.pdf [Accessed: $4^{\text {th }}$ November 2017].

Drucker, S. J. and Cathcart, R. S. (1994) (Eds) American heroes in a media age, Cresskill, New Jersey: Hampton Press. 
Dunham, D and Jayasuriya, S. (1999) He who pays the piper: mephistopheles and the opiate of one day cricket, In Jayadeva Uyangoda (Ed.) Cricket, Lovely Cricket: Sports in Culture, Class and Nation in Sri Lanka, Colombo: Social Scientists Association of Sri Lanka, pp: 28-40.

Durkheim, E. (1951) Suicide (trans. John A. Spaulding and George Simpson) Glencoe, Illinois.: Free Press.

Entman, R. M. (1993) Framing: Toward clarification of a fractured paradigm, Journal of Communication, 43, pp: 51-58. DOI: https://doi.org/10.1111/j.1460-2466.1993.tb01304.x

Fernando, C. (2017a) Mathews, Malinga excluded from Pakistan ODIs, Daily Mirror [Online] $4^{\text {th }}$ October, Available from: http://www.dailymirror.lk/cricket-news/MathewsMalinga-excluded-from-Pakistan-ODIs/320-1378481 [Accessed: $6^{\text {th }}$ March 2018].

Fernando, C. (2017b) Chandimal, Tharanga replace Angelo, Daily Mirror [Online] 12 ${ }^{\text {th }}$ July, Available from: http://www. dailymirror.lk/article/Chandimal-Tharanga-replace-Angelo-asTests-and-limited-over-captains-132621.html [Accessed: $7^{\text {th }}$ September 2017].

Fernando, C. (2017c) Don't rotate Players too often-Upul Thranga, Daily Mirror [Online] $15^{\text {th }}$ May, Available from: http:// www.dailymirror.lk/cricket-news/Don-t-rotate-players-toooften-Upul-Tharanga/320-129241 [Accessed: $7^{\text {th }}$ September 2017].

Fernando, C. (2017d) Lowest point in my career- Mathews, Daily Mirror [Online] 10 $0^{\text {th }}$ July, Available from: http://www. dailymirror.1k/cricket-news/Lowest-point-in-my-careerMathews/320-132575 [Accessed: $5^{\text {th }}$ November 2017].

Fernando, C. (2017e) Chronology of cricket disaster, Sunday Times [Online] $6^{\text {th }}$ August, Available from: http://www. sundaytimes.lk/170806/sports/chronology-of-a-cricketdisaster-253241.html [Accessed: $5^{\text {th }}$ November 2017].

Ferriter, M. (2008) Heroes and Zeroes: Extending Celebrity Athlete Narratives Beyond Retirement, Football Studies, 10(1/2) [Online] Available from: https://www.academia. edu/3415790/HEROES_AND_ZEROES_Extending_ Celebrity_Athlete_Narratives_Beyond_Retirement [Accessed on: $9^{\text {th }}$ October 2017].

Franzosi , R. and Vicari , S. (2013) What's in a Text? Answers from Frame Analysis and Rhetoric for Measuring Meaning Systems and Argumentative Structures [Online] Available from: https:/www.unive.it/media/allegato/Scuola-Dottorale/2013/ Rhetoric_and_Frame_Analysis_May_2013.pdf [Accessed on:

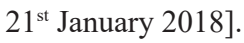

Ganguly, L. (2005) Playing Nations, Watching TV: The Culture of Politics and the Politics of Culture - Cricket in South Asia [Online] Available from: http://www.allacademic.com/meta/ p71424_index.html [Accessed on:2 $1^{\text {st }}$ October 2017].
Ghosh, D. (2017) India savour unprecedented whitewash, Times of India [Online] 21 ${ }^{\text {st }}$ September, Available from: https://timesofindia.indiatimes.com/sports/cricket/indiain-sri-lanka/india-savour-unprecedented-whitewash/ articleshow/60418169.cms [Accessed: $13^{\text {th }}$ November 2017].

Giles, D. (2000) Illusions of Immortality: A Psychology of Fame and Celebrity, Basingstoke, United Kingdom: Palgrave, Macmillan.

DOI: https://doi.org/10.1007/978-1-137-09650-0

Giles, D. (2008) Media Framing Analysis, Media Psychology Review, 1(1) [Online] Available from: http://mprcenter.org/ review/gilesmedia-framing/ [Accessed: $16^{\text {th }}$ January 2018].

Gladson, J. A. C (2017) Mumbai beat Pune by one run to claim their third IPL crown, Times of India [Online] 22 nd May, Available from: https://timesofindia.indiatimes.com/ sports/cricket/ipl/top-stories/mumbai-beat-pune-by-one-runto-claim-their-third-ipl-crown/articleshow $/ 58782851 . \mathrm{cms}$ [Accessed: $8^{\text {th }}$ March 2018].

Goffman, E. (1974) Frame Analysis, New York: Harper and Row.

Gupta, G. (2017) CAC will only explain role of coach to Virat Kohli, Times of India [Online] 11 $11^{\text {th }}$ July, Available from: https://timesofindia.indiatimes.com/sports/cricket/ news/cac-will-only-explain-role-of-coach-to-virat-kohli/ articleshow/59537830.cms [Accessed: $7^{\text {th }}$ December 2017].

Hallahan, K. (1999) Seven models of framing: Implications for public relations, Journal of Public Relations Research, 11(3), pp: 205-242.

DOI: https://doi.org/10.1207/s1532754xjprr1103_02

Hanson (2017) Building Personal and Performance Character in Sport [Online] Available from: https://athleteassessments. com/Building-Personal-And-Performance-Character-In-Sport/ [Accessed: $15^{\text {th }}$ January 2018].

Hargreaves, J. (1986) Where's the virtue? Where's the grace? A discussion of the social production of gender through sport, Theory Culture and Society, 3(1), pp: 109-122.

DOI: https://doi.org/10.1177/0263276486003001010

Harris, J. C. (1994) Athletes and the American hero dilemma, Sport Science Monograph Series, 4, Champaign, Illinois: Human Kinetics.

Holt, R. (1996) Heroes of the North: Sport and the Shaping of Regional Identity, In J. Hill and J. Williams (Eds.) Sport and Identity in the North of England, Staffordshire, UK: Keele University Press.

Hussain F. (2014) Media representation of sports and sportspersons: A study of trends with specific reference to India, 
Ph. D. [Online] Available from: http://shodhganga.inflibnet. ac.in/handle/10603/160871 [Accessed: $12^{\text {th }}$ December 2017].

Iyengar, S. (1991) Is anyone responsible? How television frames political issues, Chicago, Illinois: University of Chicago Press.

D O I : h t t p s : / / d o i.org/ $10.7208 /$ chicago/9780226388533.001.0001

Joseph, A. I. (2017) Dhoni is still the captain in the dressing room, Daily Mirror [Online] $3^{\text {rd }}$ September, Available from: https://timesofindia.indiatimes.com/city/chennai/dhoni-is-stillthe-captain-in-the-dressing-room/articleshow/60337618.cms [Accessed: 12 ${ }^{\text {th }}$ December 2017].

Kennedy, E. and Hills, L. (2009) Sport, Media and Society, Oxford, United Kingdom: Berg Publishers.

Krishnamohan, T. (2017) Lasith Malinga-A team's hero but the media's villain [Online] Available from: https://www. sportskeeda.com/cricket/lasith-malinga-teams-hero-mediasvillain [Accessed: $14^{\text {th }}$ December 2017].

Lewis, N. and Weaver A. J. (2013) More Than a Game: Sports Media Framing Effects on Attitudes, Intentions, and Enjoyment, Communication \& Sport, 3(2), pp: 219-242 [Online] Available from: https://www.researchgate.net/publication/270671608_ More_Than_a_Game_Sports_Media_Framing_Effects_ on_Attitudes_Intentions_and_Enjoyment [Accessed: $18^{\text {th }}$ December 2017].

Mathur, A. (2017) I was waiting for Dhoni to give me that last over, Times of India [Online] $24^{\text {th }}$ September, Available from https://timesofindia.indiatimes.com/city/gurgaon/jogindersharma-on-2007-world-t20-win-i-was-waiting-for-dhoni-togive-me-that-last-over/articleshow/60807962.cms [Accessed: $5^{\text {th }}$ November 2017].

Milner, M. (2010) Is celebrity a new kind of status system?, Society, 47(5), pp: 379-387 [Online] Available from: https://pdfs.semanticscholar.org/4b85/ ad69ce9332b207ab6f9e36e2be6a1c21b303.pdf [Accessed: $21^{\text {st }}$ October 2017].

Mukharjee, J. (2004) Media and Politics: An Indian Perspective, Parliamentary Affairs, 57(1), pp: 80- 92.

DOI: https://doi.org/10.1093/pa/gsh007

Naha, S. (2012) Producing the First Indian Cricketing Superhero: Nationalism, Body Culture, Consumption and the CK Nayudu Phenomenon, The International Journal of the History of Sport, 29(4), pp: 562-582.

DOI: https://doi.org/10.1080/09523367.2012.658190

Naik, N. (2017) IPL 2017: Invisible captain Dhoni behind Pune's rise, Times of India [Online] 17 ${ }^{\text {th }}$ May 2017, Available from: https://timesofindia.indiatimes.com/sports/cricket/ipl/ top-stories/ipl-2017-invisible-captain-dhoni-behind-risingpune-supergiants-rise/articleshow/58718027.cms [Accessed: $6^{\text {th }}$ August 2017].

Nalapat, A. and Parker, A. (2005) Sport, Celebrity and Popular Culture: Sachin Tendulkar, Cricket and Indian Nationalisms, International Review for the Sociology of Sport, 40(4), pp: 433-446.

DOI: https://doi.org/10.1177/1012690205065750

North, A. C., Bland, V. and Ellis, N. (2005) Distinguishing heroes from celebrities, British Journal of Psychology, 96(1), pp: $39-52$.

DOI: https://doi.org/10.1348/000712604X15473

Panarov, N. (2015) A study about the role and importance of narrative in creating a sports hero and the way digital media influences audiences, M. Sc., NHTV Breda University of Applied Sciences [Online] Available from: https://www.kennisbanksportenbewegen. $\mathrm{nl} /$ ? file $=6398 \& \mathrm{~m}=1460550729 \&$ action $=$ file. downloads [Accessed: 13 ${ }^{\text {th }}$ July 2017].

Polkinghorne, D. (1988) Narrative Knowing and the Human Sciences, New York: State University of New York Press.

Prasad, R. S. (2017) Srinivasan hopes MS Dhoni will be back to lead CSK next season, Times of India [Online] $1^{\text {st }}$ April, Available from: https:/timesofindia.indiatimes.com/sports/ cricket/ipl/top-stories/srinivasan-hopes-ms-dhoni-will-beback-to-lead-csk-next-season/articleshow/57956539.cms [Accessed: $7^{\text {th }}$ December 2018].

Press Trust of India (2017a) $1^{\text {st }}$ ODI: Pandya, Dhoni guide India to easy win over Australia, Times of India [Online] $18^{\text {th }}$ September, Available from: https:/timesofindia.indiatimes. com/sports/cricket/australia-in-india/live-updates-indiavs-australia-1 st-odi-chennai/articleshow/60718669.cms [Accessed: $5^{\text {th }}$ November 2017].

Press Trust of India (2017aa) Dare are to dream, a mantra learnt from 'alumni' Dhoni, Times of India [Online] $10^{\text {th }}$ October, Available from: https:/timesofindia.indiatimes.com/sports/ off-the-field/dare-are-to-dream-a-mantra-learnt-from-alumnidhoni/articleshow/61019613.cms [Accessed: $13^{\text {th }}$ November 2017].

Press Trust of India (2017ab) To practice what he preaches, Kohli drops Pepsi, fairness products, Times of India [Online] $16^{\text {th }}$ September, Available from: https://timesofindia.indiatimes. com/sports/off-the-field/to-practice-what-he-preaches-kohlidrops-pepsi-fairness-products/articleshow/60708947.cms [Accessed: 13 ${ }^{\text {th }}$ November 2017].

Press Trust of India (2017ac) Virat Kohli expects no added pressure on working with Ravi Shastri, Times of India [Online] $19^{\text {th }}$ July, Available from: https://timesofindia.indiatimes.com/ 
sports/cricket/india-in-sri-lanka/virat-kohli-expects-no-addedpressure-on-working-with-ravi-shastri/articleshow/59666571. cms [Accessed: $13^{\text {th }}$ November 2017].

Press Trust of India (2017ad) $5^{\text {th }}$ ODI : India beat Sri Lanka, win series in 5-0 whitewash, WION [Online] $3^{\text {rd }}$ September, Available from: http://13.126.126.4/cricket/5th-odi-india-beatsri-lanka-win-series-in-5-0-whitewash-19822 [Accessed: $13^{\text {th }}$ November 2017].

Press Trust of India (2017ae) Jhulan Goswami hails 'phenomenal' Virat Kohli; advises him to continue playing his brand of cricket, First Cricket [Online] $16^{\text {th }}$ September, Available from: https:/www.firstpost.com/firstcricket/sportsnews/jhulan-goswami-hails-phenomenal-virat-kohli-adviseshim-to-continue-playing-his-brand-of-cricket-4050483.html [Accessed: 13 ${ }^{\text {th }}$ November 2017].

Press Trust of India (2017af) AB De Villiers dislodges Virat Kohli to take top spot in ODI ranking, Times of India [Online] $20^{\text {th }}$ October, Available from: https://timesofindia.indiatimes. com/sports/cricket/news/ab-de-villiers-dislodges-virat-kohlito-take-top-spot-in-odi-rankings/articleshow/61153852.cms [Accessed: 13 ${ }^{\text {th }}$ November 2017].

Press Trust of India (2017ag) Virat Kohli, sole Indian in Forbes List of highest paid athletes, Times of India [Online] 8th June, Available from: https://timesofindia.indiatimes.com/sports/offthe-field/virat-kohli-sole-indian-in-forbes-list-of-highest-paidathletes/articleshow/59047378.cms [Accessed: $13^{\text {th }}$ November 2017].

Press Trust of India (2017ah) Dhoni leaves Kotla separately after Jharkhand's semi-final defeat, Times of India [Online] $18^{\text {th }}$ March, Available from: https://timesofindia.indiatimes. $\mathrm{com} /$ sports/cricket/news/dhoni-leaves-kotla-separately-afterjharkhands-semi-final-defeat/articleshow/57709542.cms [Accessed: $9^{\text {th }}$ November 2017].

Press Trust of India (2017ai) Don't play for tons and that's why I cross it more: Kohli, Times of India [Online] $16^{\text {th }}$ September, Available from: https:/timesofindia.indiatimes.com/sports/ cricket/australia-in-india/dont-play-for-tons-and-thats-why-icross-it-more-kohli/articleshow/60711259.cms [Accessed: $9^{\text {th }}$ November 2017].

Press Trust of India (2017aj) Dhoni need not prove anything to anyone: Shane Warne, Times of India [Online] $18^{\text {th }}$ April, Available from: https:/timesofindia.indiatimes.com/sports/ cricket/ipl/top-stories/dhoni-need-not-prove-anything-toanyone-shane-warne/articleshow/58235977.cms [Accessed: $9^{\text {th }}$ November 2017].

Press Trust of India (2017ak) You will always be our captain: Kohli on Dhoni on 300 ODIs, Times of India [Online] $31^{\text {st }}$ August, Available from: https:/timesofindia.indiatimes.com/sports/ cricket/india-in-sri-lanka/you-will-always-be-our-captainkohli-on-dhoni-playing-300-odis/articleshow/60311790.cms [Accessed: $13^{\text {th }}$ November 2017].
Press Trust of India (2017b) Spotlight on Nehra, India look to turn tables in T20s against New Zealand, Times of India [Online] $31^{\text {st }}$ October, Available from: https://timesofindia. indiatimes.com/sports/cricket/new-zealand-in-india/spotlighton-nehra-india-look-to-turn-tables-in-t20s-against-newzealand/articleshow/61356910.cms [Accessed: $5^{\text {th }}$ November 2017].

Press Trust of India (2017c) IPL GC proposal may ease dhoni's return to Chennai Super Kings, Times of India [Online] 24 $4^{\text {th }}$ October, Available from: https://timesofindia.indiatimes.com/ sports/cricket/ipl/top-stories/ipl-gc-proposal-may-ease-dhonisreturn-to-chennai-super-kings/articleshow/61200284.cms [Accessed: $5^{\text {th }}$ November 2017].

Press Trust of India (2017d) Under pressure India faces rare series defeat at home, Times of India [Online] $24^{\text {th }}$ October, Available from: https:/timesofindia.indiatimes.com/sports/ cricket/new-zealand-in-india/under-pressure-india-face-rareseries-defeat-at-home/articleshow/61198237.cms [Accessed: $10^{\text {th }}$ November 2017].

Press Trust of India (2017e) I am like wine: Dhoni on getting better with age, Times of India [Online] $1^{\text {st } J u l y, ~ A v a i l a b l e ~ f r o m: ~}$ https://timesofindia.indiatimes.com/sports/cricket/india-inwest-indies/i-am-like-wine-dhoni-on-getting-better-with-age/ articleshow/59397578.cms [Accessed: $10^{\text {th }}$ November 2017].

Press Trust of India (2017f) Players like Dhoni should always be respected: says Raina, The Hindu [Online] 20 $0^{\text {th }}$ April, Available from: https://www.thehindu.com/sport/cricket/ player-like-dhoni-should-always-be-respected-says-raina/ article18154722.ece [Accessed: 10 ${ }^{\text {th }}$ November 2017].

Press Trust of India (2017g) Kohli equals Tendulkar's feat, Bumrah jumps to 4th in ODI ranking, The Hindu [Online] $4^{\text {th }}$ September, Available from: https://www.thehindu.com/ sport/cricket/india-tour-of-sri-lanka-sri-lanka-vs-india-odiseries-kohli-equals-tendulkars-feat-bumrah-jumps-to-4thin-rankings/article19619394.ece [Accessed: 10 ${ }^{\text {th }}$ November 2017].

Press Trust of India (2017h) Kohli's 82 guides India to clean sweep across formats in Sri Lanka, The Pioneer [Online] $6^{\text {th }}$ September, Available from: https://www.dailypioneer. com/2017/sports-bytes/kohlis-82-guides-india-to-cleansweep-across-formats-in-lanka.html [Accessed: $9^{\text {th }}$ November 2017].

Press Trust of India (2017i) Smith picks Tendulkar, Harbhajan ahead of Kohli in his dream team, The Hans India [Online] $21^{\text {st }}$ September, Available from: https://www.thehansindia. com/posts/index/Sports/2017-09-20/Smith-picks-TendulkarHarbhajan-ahead-of-Kohli-in-his-dream-team/327901 [Accessed: $9^{\text {th }}$ November 2017].

Press Trust of India (2017j) M.S. Dhoni's daughter stun fans by singing Malayalam song, Times of India [Online] $25^{\text {th }}$ October, Available from: https://www.timesnownews.com/ 
sports/article/watch-ms-dhonis-daughter-ziva-sets-internet-onfire-by-singing-malayalam-song-fluently/112893 [Accessed: $4^{\text {th }}$ May 2018].

Press Trust of India (2017k) Vijay Hazare Trophy: Dhoni signs autograph while batting in middle, Times of India [Online] $15^{\text {th }}$ March, Available from: https:/timesofindia.indiatimes. com/sports/cricket/news/vijay-hazare-trophy-dhoni-signsautograph-while-batting-in-middle/articleshow/57656503.cms [Accessed: $4^{\text {th }}$ May 2018].

Press Trust of India (20171) M. S. Dhoni's Aadhaar details leaked on Twitter, wife Sakshi complains to IT minister, Times of India [Online] 29 $9^{\text {th }}$ March, Available from: https:// timesofindia.indiatimes.com/india/ms-dhonis-aadhar-detailsleaked-on-twitter-wife-sakshi-complains-to-it-minister/ articleshow/57886970.cms [Accessed: $10^{\text {th }}$ November 2017].

Press Trust of India (2017m) He is the second most popular Indian personality on Facebook, only behind Indian Prime Minister Narendra Modi, Times of India [Press release] 26 $6^{\text {th }}$ June, Available from: https://timesofindia.indiatimes.com/ sports/off-the-field/this-is-a-bi-product-of-what-we-do-onfield-virat-kohli-on-becoming-2nd-most-followed-indianon-facebook/articleshow/59317994.cms [Accessed: $10^{\text {th }}$ November 2017].

Press Trust of India (2017n) $5^{\text {th }}$ ODI: Virat Kohli century seals 5-0 clean sweep against Sri Lanka, Times of India [Online] $3^{\text {rd }}$ September, Available from: https://timesofindia.indiatimes. com/sports/cricket/india-in-sri-lanka/india-vs-sri-lanka-5thodi-live-updates/articleshow/60348168.cms [Accessed: $10^{\text {th }}$ November 2017].

Press Trust of India (2017o) To teach Virat Kohli a lesson! An engineer applies for coach's post, The New Indian Express [Online] 27 $7^{\text {th }}$ June, Available from: http://www. newindianexpress.com/sport/cricket/2017/jun/27/toteach-virat-kohli-a-lesson-an-engineer-applies-for-coachspost-1621560.html [Accessed: $10^{\text {th }}$ November 2017].

Press Trust of India (2017p) Virat Kohli stays away from social media while Sarfaaz Ahmed thanks it, Times of India [Online] $18^{\text {th }}$ June, Available from: https:/timesofindia. indiatimes.com/sports/cricket/champions-trophy-2017/viratkohli-stays-away-from-social-media-sarfraz-ahmed-thanks-it/ articleshow/59195599.cms [Accessed: $5^{\text {th }}$ November 2017].

Press Trust of India (2017q) Pakistani fan mocks Virat Kohli, Times of India [Online] 20 $0^{\text {th }}$ June, Available from: https:// timesofindia.indiatimes.com/sports/cricket/championstrophy-2017/top-stories/watch-pakistani-fan-mocks-viratkohli/articleshow/59229813.cms [Accessed: $5^{\text {th }}$ November 2017].

Press Trust of India (2017r) I feel the heat more as a captain, Daily Mirror [Online] 24 ${ }^{\text {th }}$ January, Available from: http:// www.dailymirror.lk/breaking_news/I-Feel-the-heat-moreas-captain-Mathews-/108-122605 [Accessed: $5^{\text {th }}$ November 2017].
Press Trust of India (2017s) ICC Champions Trophy 2017: Don't agree on everything with MS Dhoni, says Virat Kohli, Cricket Country [Online] $3^{\text {rd }}$ June, Available from: http:// staging.cricketcountry.com/news/icc-champions-trophy2017-dont-agree-on-everything-with-ms-dhoni-says-viratkohli-613014 [Accessed: $5^{\text {th }}$ November 2017].

Press Trust of India (2017t) Champion's Trophy would decide Dhoni's fate, says childhood coach, Times of India [Online] $13^{\text {th }}$ March, Available from: https://timesofindia.indiatimes. com/sports/cricket/news/champions-trophy-would-decidedhonis-fate-says-childhood-coach/articleshow/57618825.cms [Accessed: 18 ${ }^{\text {th }}$ January 2018].

Press Trust of India $(2017 \mathrm{u})$ Not sure if Dhoni is still a good T20 player: Ganguly, Times of India [Online] $13^{\text {th }}$ April, Available from: https:/timesofindia.indiatimes.com/sports/ cricket/ipl/top-stories/not-sure-if-dhoni-is-still-a-good-t20player-ganguly/articleshow $/ 58151757 . \mathrm{cms} \quad$ [Accessed: $18^{\text {th }}$ January 2018].

Press Trust of India $(2017 \mathrm{v})$ India are ruthless side with immense work ethics, Times of India [Online] $7^{\text {th }}$ September, Available from: https:/timesofindia.indiatimes.com/sports/ cricket/india-in-sri-lanka/india-are-a-ruthless-side-withimmense-work-ethics-pothas/articleshow/60404860.cms [Accessed: $13^{\text {th }}$ November 2017].

Press Trust of India (2017w) Picking right players for each format is key to success, says Kohli, Times of India [Online] $8^{\text {th }}$ October, Available from: https://www.thehindu.com/sport/ cricket/australia-tour-of-india-india-vs-australia-first-t20international-match-at-ranchi/article19822745.ece [Accessed: $13^{\text {th }}$ November 2017].

Press Trust of India (2017x) Kohli's aggression has become India's strength, says Tendulkar, Times of India [Online] $23^{\text {rd }}$ October, Available from: https://www.deccanherald.com/ content/639055/kohlis-aggression-has-become-indias.html [Accessed: $13^{\text {th }}$ November 2017].

Press Trust of India (2017y) No need of a coach if Kohli thinks he is the boss: Prasanna, Eastern Mirror [Online] $23^{\text {rd }}$ June, Available from: http://www.easternmirrornagaland.com/ no-need-of-a-coach-if-kohli-thinks-he-is-the-boss-prasanna/ [Accessed: 13 ${ }^{\text {th }}$ November 2017].

Press Trust of India (2017z) BCCI nominates MS Dhoni for Padma Bhushan Award, Times of India [Online] $20^{\text {th }}$ September, Available from: https:/timesofindia.indiatimes.com/sports/ cricket/news/bcci-nominates-ms-dhoni-for-padma-bhushanaward/articleshow/60763268.cms [Accessed: 13 ${ }^{\text {th }}$ November 2017].

Price, V., Tewksbury, D. and Powers, E. (1997) Switching trains of thought: The impact of news frames on readers' cognitive responses, Communication Research, 24, pp: 481-506.

DOI: https://doi.org/10.1177/009365097024005002 
Rao, K. S. (2017) Virat Kohli must know how coaches work, Times of India [Online] $11^{\text {th }}$ July, Available from: https://imesofindia.indiatimes.com/sports/cricket/news/ virat-kohli-must-know-how-coaches-work-sourav-ganguly/ articleshow/59537973.cms [Accessed: $18^{\text {th }}$ January 2018].

Rojek, C. (2006) Sports Celebrity and The Civilizing Process, Sport in Society: Cultures, Commerce, Media, Politics, 9(4), pp: 674-690 [Online] Available from: https://www.tandfonline. com/doi/full/10.1080/17430430600769106 [Accessed 13 ${ }^{\text {th }}$ July 2017].

Rosen, J. N., Smith, M. M. and Park, R. J. (Eds.) (2016) More than Cricket and Football, International Sport and The Challenge of Celebrity, USA: University Press of Mississippi.

D O I : h t t p s : / / d o i.org/10.14325/ mississippi/9781496809889.001.0001

Saharoy, S. (2017) MS Dhoni deserves to go on his terms: Mike Hussey, Times of India [Online] $16^{\text {th }}$ August, Available from: https://timesofindia.indiatimes.com/sports/cricket/ news/ms-dhoni-deserves-to-go-on-his-terms-mike-hussey/ articleshow/60080558.cms [Accessed: $18^{\text {th }}$ January 2018].

Sahajeewa, W. M. D. (2015) Preference of Sports Journalism in Sri Lanka, International Journal of Scientific and Research Publications, 5(10) [Online] Available from: http://www. ijsrp.org/research-paper-1015/ijsrp-p4655.pdf [Accessed: $21^{\text {st }}$ October 2017].

Sangakkara, K. (2017) Timid Sri Lanka let South Africa off the hook-Sanga, Daily Mirror [Online] $5^{\text {th }}$ June, Available from: http://www.dailymirror.lk/cricket-news/Timid-Sri-Lanka-letSouth-Africa-off-the-hook-Sanga/320-130235 [Accessed: $7^{\text {th }}$ July 2017].

Scheufele, D. A. (1999) Framing as a theory of media effects, Journal of Communication, 49(1), pp: 103-122.

DOI: https://doi.org/10.1093/joc/49.1.103

Shoemaker, P. J. and Reese, S. D. (1996) Mediating the message: Theories of influences on mass media content $\left(2^{\text {nd }}\right.$ Ed.) White Plains, New York.: Longman [Online] Available from: https://chinhnghia.com/mediating-the-message.pdf [Accessed: 12 ${ }^{\text {th }}$ December 2017].

Shuart, J. (2004) The Media Dichotomy of Sports Heroes and Sport Celebrities: The Marketing of Professional Women Tennis Players, In J. Murdy (Ed.) Proceedings of the 2003 Northeastern Recreation Research Symposium, 2003 April 6-8, pp: 145151, Newtown Square, Pennsylvania: Northeastern Research Station, U. S. Department of Agriculture, Forest Service.

Sreekumar, S. (2016) Media Representation and Celebrity Discourse: Editorial Approaches to Sachin Tendulkar's Retirement, Media Watch, 7(2), pp: 200-209 [Online] Available from: https://www.academia.edu/34212111/ Media_Representation_and_Celebrity_Discourse_Editorial_ Approaches_to_Sachin_Tendulkars_Retirement_docx [Accessed: $12^{\text {th }}$ December 2017]. thebusinessprofessor.com, Cognitive Framing in Negotiation [Online] Available from: https://thebusinessprofessor.com/ knowledge-base/cognitive-framing-in-negotiation/ [Accessed: $13^{\text {th }}$ May 2017].

Thomas, S. (2017) Angelo Mathews- A man who has met with triumph and disaster, Daily Mirror [Online] $8^{\text {th }}$ June, Available from: http://www.dailymirror.lk/cricket-news/ Angelo-Mathews-A-man-who-has-met-with-triumph-anddisaster-/320-130956 [Accessed: $6^{\text {th }}$ March 2017].

Times of India (2017a) Kohli, Yuvraj and Dhoni pose for pictures with Azhar Ali's kids, Times of India [Online] $20^{\text {th }}$ June, Available from: https://timesofindia.indiatimes.com/ sports/off-the-field/kohli-yuvraj-and-dhoni-pose-for-pictureswith-azhar-alis-kids/articleshow/59235829.cms [Accessed: $18^{\text {th }}$ January 2018].

Times of India (2017b) IPL 2017 Final: Mohammad Azharuddin feels Rising Pune Supergiant will win the title, Times of India [Online] $21^{\text {st }}$ May, Available from: https://timesofindia. indiatimes.com/sports/cricket/ipl/top-stories/ipl-2017-finalmohammad-azharuddin-feels-rising-pune-supergiant-willwin-the-title/articleshow $/ 58775532 . \mathrm{cms} \quad$ [Accessed: $18^{\text {th }}$ January 2018].

Times of India (2017c) Virat Kohli showers praises on Afghanistan cricket team, wishes them success, Times of India [Online] 15 $5^{\text {th }}$ October, Available from: https://timesofindia. indiatimes.com/sports/cricket/watch-virat-kohli-showerspraises-on-afghanistan-cricket-team-wishes-them-success/ articleshow/61089181.cms [Accessed: $18^{\text {th }}$ January 2018].

Times of India (2017d) Virat Kohli best batsman in the world: Mohammad Amir, Times of India [Online] $18^{\text {th }} \mathrm{July,} \mathrm{Available}$ from: https://timesofindia.indiatimes.com/sports/cricket/news/ virat-kohli-best-batsman-in-the-world-mohammad-amir/ articleshow/59645391.cms [Accessed: $18^{\text {th }}$ January 2018].

Turner, G. (2006) The Mass Production of Celebrity: 'Celetoids', Reality TV and the 'Demotic Turn', International Journal of Cultural Studies, 9(2), pp: 153-165.

DOI: https://doi.org/10.1177/1367877906064028

Tversky, A. and Kahneman, D. (1981) The framing of decisions and the psychology of choice, Science, 211, pp: 453-458 [Online] Available from: https://www.uzh.ch/cmsssl/suz/ dam/jcr:ffffffff-fad3-547b-ffff-ffffe54d58af/10.18_kahneman tversky_81.pdf [Accessed: $12^{\text {th }}$ December 2017].

Waller, L. and Oakham, K. M. (2009) The Carey 'king hit': journalists and the coverage of domestic violence, Asia Pacific Media Educator, June 2008-July 2009: 19, pp: 71 - 84.

Waller, R. and Conaway, R. (2011) Framing and counterframing the issue of corporate social responsibility, Journal of Business Communication, 48(1), pp: 83-106.

DOI: https://doi.org/10.1177/0021943610389752 
Wenner, L. A. (2013) The fallen sports hero in the age of mediated celebrityhood, Fallen sports heroes, media, \& celebrity culture, pp: 3-16.

Whannel, G. (2002) Media Sport Stars: Masculinities and Moralities, New York: Routledge.

Wijeyeratne, P. de S. (2017) Will Sri Lanka be able to challenge the Indians?, Daily Mirror [Online] $5^{\text {th }}$ August, Available from: http://www.dailymirror.lk/article/Will-Sri-Lanka-be-able-
to-challenge-the-Indians--134207.html [Accessed: $13^{\text {th }}$ May 2017].

Wilson, D. (2017) Beleaguered England bowlers ask batsmen to Clout It Like Kohli in training to help them tame runmachine Virat, Mirror [Online] $17^{\text {th }}$ January, Available from: https://www.mirror.co.uk/sport/cricket/beleaguered-englandbowlers-ask-batsmen-9639387 [Accessed: 13 ${ }^{\text {th }}$ May 2017].

Zimbardo, P. G. (2007) The Lucifer effect: Understanding how good people turn evil, New York: Random House.

\section{APPENDIX}

Unique and Common Hero and Celebrity Dimensions in terms of high/low character and performance

\begin{tabular}{|c|c|c|c|c|}
\hline \multicolumn{4}{|l|}{ Unique dimensions } & \multirow{2}{*}{$\begin{array}{l}\text { Dimensions common to } \\
\text { Hero and Celebrity (High/ } \\
\text { low Performance) }\end{array}$} \\
\hline Hero (High Performance) & Hero (Low Performance) & $\begin{array}{l}\text { Celebrity } \\
\text { (High Performance) }\end{array}$ & $\begin{array}{l}\text { Celebrity } \\
\text { (Low Performance) }\end{array}$ & \\
\hline \multicolumn{2}{|c|}{ Fuelled by individual performance indicators } & \multicolumn{2}{|c|}{ Fuelled by social performance indicators } & \\
\hline Inspirational & $\begin{array}{l}\text { Sustaining injury or } \\
\text { being ill }\end{array}$ & $\begin{array}{l}\text { Well rounded image/ } \\
\text { expertise off the field }\end{array}$ & Lack of image off the field & $\begin{array}{l}\text { Presence or absence of } \\
\text { characteristic style of play }\end{array}$ \\
\hline Leadership & Lack of leadership & $\begin{array}{l}\text { Strong presence in more } \\
\text { mainstream life }\end{array}$ & $\begin{array}{l}\text { Weak presence in more } \\
\text { mainstream life }\end{array}$ & $\begin{array}{l}\text { Marriage/Divorce/ } \\
\text { parenthood }\end{array}$ \\
\hline Team Spirit & Lack of team spirit & $\begin{array}{l}\text { Expert, Experienced, } \\
\text { Knowledgeable, Qualified } \\
\text { or Skilled }\end{array}$ & $\begin{array}{l}\text { Not Expert, Experienced, } \\
\text { Knowledgeable, Qualified } \\
\text { or Skilled }\end{array}$ & $\begin{array}{l}\text { Shallowness (the opposite } \\
\text { of competence) }\end{array}$ \\
\hline Commitment & Lack of commitment & Characteristic style of play & $\begin{array}{l}\text { No Characteristic style } \\
\text { of play }\end{array}$ & Equanimity/composure, \\
\hline Hard work & Laziness & $\begin{array}{l}\text { Earns more off the field } \\
\text { than on }\end{array}$ & $\begin{array}{l}\text { Not necessarily earning } \\
\text { off the field than on }\end{array}$ & Self-assurance/confidence \\
\hline Determination & Lack of determination & Credible & Low credibility & Flawed Complexity \\
\hline Overcoming injury/illness & $\begin{array}{l}\text { Debilitated by constant } \\
\text { injury }\end{array}$ & Genuineness & Not genuine & $\begin{array}{l}\text { Bringing the game into } \\
\text { repute/disrepute through } \\
\text { acts on and off the field }\end{array}$ \\
\hline Crucial decision making & $\begin{array}{l}\text { Lack of decision } \\
\text { making at crucial points }\end{array}$ & Likeable/ Sociability & Not liked or non- sociable & Ordinariness \\
\hline Extraordinary skill/talent, & Low talents, skills & Attractive & Not attractive & Drive for affiliation \\
\hline Diligence/perseverance & Lack of perseverance & Exciting & Insipid & Compartmentalisation \\
\hline Obligation/commitment & Lack of commitment & $\begin{array}{l}\text { Bringing the game repute } \\
\text { through acts on and off } \\
\text { the field }\end{array}$ & $\begin{array}{l}\text { Bringing the game into } \\
\text { disrepute through acts on } \\
\text { and off the field }\end{array}$ & $\begin{array}{l}\text { Visibility on and off sports } \\
\text { field }\end{array}$ \\
\hline Passion & Lack of passion & $\begin{array}{l}\text { Incorporated- } \\
\text { embourgeoised }\end{array}$ & Supertars-disclocated & \\
\hline $\begin{array}{l}\text { Overcoming injury/ } \\
\text { illness to accomplish } \\
\text { extraordinary acts }\end{array}$ & $\begin{array}{l}\text { Unable to overcome } \\
\text { injury, thus affecting } \\
\text { performance }\end{array}$ & $\begin{array}{l}\text { High Influence off the field } \\
\text { on fans - role model due } \\
\text { to lifestyle }\end{array}$ & $\begin{array}{l}\text { Low Influence off the field } \\
\text { on fans - not a role model } \\
\text { due to lifestyle }\end{array}$ & \\
\hline Humility & Lack of humility - ego & $\begin{array}{l}\text { Marketable lifestyle - } \\
\text { Life Story Role Model } \\
\text { Relationship Effort }\end{array}$ & & \\
\hline Strength/endurance & Lack of endurance & $\begin{array}{l}\text { Less visible less on the } \\
\text { sport field, but much more } \\
\text { noticeable outside it. }\end{array}$ & & \\
\hline
\end{tabular}


Continued from page 39

$\begin{array}{ll}\text { Characteristic style of play } & \begin{array}{l}\text { No Characteristic style } \\ \text { of play }\end{array} \\ \text { Moral } & \text { Immoral } \\ \text { Good } & \text { Bad } \\ \text { Strong } & \text { Weak } \\ \text { Active } & \text { Inactive } \\ \text { Equanimity/Composure } & \text { Rash/irresponsible } \\ \text { Traditional- Located } & \text { Non Traditional- } \\ & \text { Located } \\ \text { Transitional-Mobile } & \begin{array}{l}\text { Non-transitional- } \\ \text { Mobile }\end{array} \\ \text { Involved in Charity } & \text { Not socially responsible } \\ \text { work - engaging with } & - \text { not engaging with } \\ \text { community } & \text { community } \\ \text { Visible on the sport field, } & \\ \text { but much less noticeable } \\ \text { outside it. }\end{array}$

